\title{
Signal Transduction in T Helper Cells: CD4 Coreceptors Exert Complex Regulatory Effects on T Cell Activation and Function
}

\section{Rolf König and Wenhong Zhou}

Department of Microbiology and Immunology and the Sealy Center for Molecular Science; University of Texas Medical Branch, 301 University Boulevard, Galveston, TX 775551070, U.S.A.

\begin{abstract}
The immune system provides a highly sophisticated surveillance mechanism to detect diverse antigens and to protect the host organism from invading pathogens and altered cells (e.g., virus-infected and tumor cells). Adaptive immune responses depend on the recognition of antigen by specific antigen receptors that are expressed on the surface of $T$ and $B$ lymphocytes. Helper $T$ cells provide regulatory functions and direct the adaptive immune system to respond appropriately to a particular antigen (i.e., cytotoxic T cell responses against viral infections and tumor cells, humoral responses against extracellular bacteria and parasitic worms). Helper T cells express CD4 coreceptors, which recognize conserved domains on proteins expressed by the class II major histocompatibility complex, the same proteins that present antigen to the $\mathrm{T}$ cell receptor. Recent progress in $\mathrm{T}$ cell biology has identified multiple regulatory functions of CD4 during thymocyte development and antigen stimulation of mature $T$ helper cells. Signaling pathways induced by engagement of CD4 independently of $\mathrm{T}$ cell receptor signaling mediate these regulatory functions. In this review, we discuss the regulation of $T$ cell signaling and emphasize the functional consequences of proper and improper CD4 coreceptor signaling.
\end{abstract}

\section{Introduction}

The immune system provides a highly sophisticated surveillance mechanism to detect diverse antigens and protect the host organism from invading pathogens and altered cells (e.g., virus-infected and tumor cells). Adaptive immune responses depend on the recognition of antigens by specific antigen receptors expressed on the surface of $T$ and $B$ lymphocytes. To initiate effector mechanisms, antigen recognition must induce intracellular signaling cascades that activate the lymphocyte and promote the differentiation to an effector cell appropriate for the

*For correspondence. Email rokonig@utmb.edu. particular antigenic challenge. Importantly, regulatory mechanisms must also be present to safeguard against inadvertent self-reactivity, which could lead to autoimmunity, and to terminate immune responses, thus avoiding overexposure of the organism to toxic effectors (e.g., cytotoxic T cells, cytokines).

T lymphocytes are derived from the lymphoid lineage of hematopoietic stem cells. T cell progenitors enter the thymus where they develop into mature $\mathrm{T}$ lymphocytes (Res and Spits, 1999). During thymic development, the immature thymocytes undergo rearrangement of first the $\beta$ and then the $\alpha$ T cell receptor (TCR) genes (Khor and Sleckman, 2002; Raulet et al., 1985). This process increases the diversity of available TCRs and assures that each T cell expresses only a single type of TCR. Only those thymocytes that have successfully completed TCR gene rearrangement will be allowed to survive. Unsuccessful rearrangement leads to programmed cell death by apoptosis.

Following rearrangement, the functionality of the maturing thymocytes is tested by interactions with thymic antigen-presenting cells (APCs). In order to be functional, the thymocytes' TCR must be able to engage epitopes formed by short peptides bound to molecules encoded by the major histocompatibility complex (MHC). Because of the large isotypic and allelic variability of MHC molecules within each species, not all recombination events of TCR genes lead to matches with a peptide/MHC complex potentially present in the individual organism. Therefore, a positive selection event is required. Two classes of MHC molecules select T cells with different functions. MHC class I molecules bind peptides derived from proteins synthesized by the presenting cell and proteolytically processed by the cell's proteasome (Niedermann, 2002). These peptides can combine with nascent MHC class I molecules in the endoplasmic reticulum (Norbury et al., 2001; Yewdell, 2001). MHC class II molecules bind peptides derived from extracellular, endocytosed proteins that are processed in lysosomes. Nascent and recycling MHC class II molecules bind these peptides while trafficking through lysosomes (Germain, 1994).

Positive selection of thymocytes requires that the interactions between the TCR and peptide/MHC complexes induce signals of sufficient strength and duration (Hogquist, 2001). Thymocytes that do not receive a TCR-mediated signal during positive selection die. Positive selection occurs on thymic stromal epithelial cells (Capone et al., 2001; Chidgey and Boyd, 2001), which do not present a full complement of all possible antigens that the T cell might encounter during its lifetime. Thus, selected T cells have partial self-reactivity and the potential to recognize antigens 
that will only be encountered later in life. The mechanisms and models of positive selection have been recently reviewed (Germain, 2002; Singer, 2002).

Maturing thymocytes express both CD4 and CD8 coreceptors. Following positive selection, one coreceptor gene is silenced (Leung et al., 2001; Taniuchi et al., 2002; Zou et al., 2001). Recent experimental results suggest that the duration of the selection signal determines lineage commitment with a short duration leading to differentiation to $\mathrm{CD}^{+}$and a long duration favoring differentiation to $\mathrm{CD}^{+}$ thymocytes (Brugnera et al., 2000; Yasutomo et al., 2000).

A negative selection step eliminates thymocytes that overtly respond to self-antigens. Estimates suggest that of all thymocytes that mature up to the double-positive $\left(\mathrm{CD} 4^{+} \mathrm{CD}^{+}\right)$stage, only about $3 \%$ complete maturation and emigrate from the thymus to peripheral lymphoid tissues (e.g., blood, lymph nodes, and spleen) (Surh and Sprent, 1994). Negative selection is mediated by thymic stromal cells or APCs (mainly dendritic cells) that migrate from peripheral organs into the thymus (Brocker, 1999). These cells provide a large battery, but not a complete complement, of different peptides derived from self and foreign proteins. Thymocytes that vigorously respond to the stimuli presented during negative selection will undergo apoptosis (Bommhardt et al., 2000; Robey and Fowlkes, 1994; Williams et al., 1999).

In this review, we will discuss signal transduction in $\mathrm{CD}^{+} \mathrm{T}$ helper (Th) cells, which regulate adaptive immune responses by promoting and directing the differentiation and activation of $B$ cells and cytotoxic $C D 8^{+} T$ cells (Schoenberger et al., 1998; Snow et al., 1994). Activation of Th cells is critical for the clearance of pathogenic infections (Diepolder et al., 1998; Taylor-Robinson and Phillips, 1992) and for the destruction of tumor cells (Kahn et al., 1991). Th cells also participate in the pathogenesis of many autoimmune disorders (Datta et al., 1997; Rizzo et al., 1996) and in transplant rejection (Bushell et al., 1995). Th cells recognize antigen in the context of $\mathrm{MHC}$ class II molecules and express the CD4 coreceptor on their cell surface, which interacts with non-polymorphic regions of MHC class II (König et al., 1992; König et al., 1995). The binding of the antigen-specific TCR to antigen/MHC class II complexes initiates Th cell activation, but the engagement of CD4 by MHC class II regulates Th cell signaling, promoting progression in the cell cycle and expression of immune response genes.

\section{T helper cell activation}

\section{The antigen-specific $T$ cell receptor}

Following thymic selection, peripheral $\mathrm{T}$ lymphocytes express a TCR that is composed of two transmembrane proteins, the $\alpha$ and the $\beta$ chains, linked by a disulfide bridge. This $\alpha \beta$ TCR is the antigen-recognition unit of the T cell, but it does not have intrinsic signaling capability. The ability to transduce intracellular signals is conveyed to the TCR via its mandatory and constitutive association with a multiprotein structure, termed the CD3- $\zeta$ complex. None of the individual components of the TCR/CD3- $\zeta$ signaling machine can be transported to the cell surface without full assembly of the complex (Sun et al., 2001).
The CD3 complex is composed of four transmembrane polypeptide chains, a $\gamma \varepsilon$ and a $\delta \varepsilon$ heterodimer. These proteins have very short extracellular domains and each intracellular domain contains a conserved protein tyrosine kinase (PTK) recognition motif, termed "Immunoreceptor Iyrosine-based Activation Motif" (ITAM). The associated, disulfide-linked $\zeta$-dimer, sometimes substituted by a $\zeta-\eta$ heterodimer, contains three ITAMs per protein chain (De Aos et al., 1997). ITAMs are substrates for src family PTKs (Iwashima et al., 1994; Weil et al., 1995), and their phosphorylation is a determining initiation event for $\mathrm{T}$ cell signaling (Qian et al., 1993).

The binding of ligands to the TCR triggers the activation of receptor-associated srcfamily PTKs, such as p56 lck and p59 ${ }^{f y n}$, leading to the rapid tyrosine phosphorylation of numerous proteins. The phosphorylation of ITAMs located in the cytoplasmic tails of $\mathrm{CD} 3$ and $\zeta_{2}$ generates binding sites for proteins bearing Src homology $2(\mathrm{SH} 2)$ domains such as the cytosolic syk family PTK " $\zeta$-associated protein of $70 \mathrm{kDa}$ " (ZAP-70) (Chan et al., 1991). Recruitment of ZAP-70 allows enhanced activation of that kinase (Lograsso et al., 1996). ZAP-70 in turn phosphorylates components of distinct downstream signaling pathways (Elder et al., 2001; Gong et al., 2001; Magnan et al., 2001). Thus, $T$ cell activation depends on the activation of both src family kinases and ZAP-70 (Figure 1).

\section{The formation of signalosomes}

The engagement of TCRs by antigen/MHC ligands induces a complex temporal and spatial arrangement of signaling complexes and networks. Slightly different compositions of these signaling machines - also termed "signalosomes" (Werlen et al., 2000) - using essentially the same components can induce different second messenger signals and lead to drastically diverse cellular responses. In addition, the dynamic assembly and disassembly of signalosomes is likely a major factor in regulating signal transduction networks. TCR signalosomes consist of transmembrane receptors, protein kinases, phosphatases and their substrates, all of which are organized into signaling machines by anchoring, adapter, and scaffolding proteins. Signalosomes connect events on the plasma membrane to distal signaling cascades, which ultimately modulate $\mathrm{T}$ cell biology. Several protein adapters, in particular "linker of activated T cells" (LAT), act as central switches that translate the quality, quantity, and duration of signals into the correct activation of specific downstream pathways (Zhang et al., 1998). Although the precise parameters that regulate the formation of signalosomes still await further clarification, recent work in this area has identified some characteristics of the signalosomes.

Formation of signalosomes is aided by compartmentalization of the plasma membrane into detergent-insoluble, sphingolipid/cholesterol-enriched micro-domains, which promote the recruitment of signal transduction molecules to the TCR signaling machine upon TCR engagement (Harder and Kuhn, 2001; Leitenberg et al., 2001). These areas of the T cell surface are also known as lipid "rafts". Palmitoylation constitutively embeds several components such as Lck, Fyn, and LAT into these lipid micro-domains, whereas others such as ZAP-70 relocalize into rafts upon TCR engagement (Harder and Kuhn, 2001; Werlen et al., 2000). 


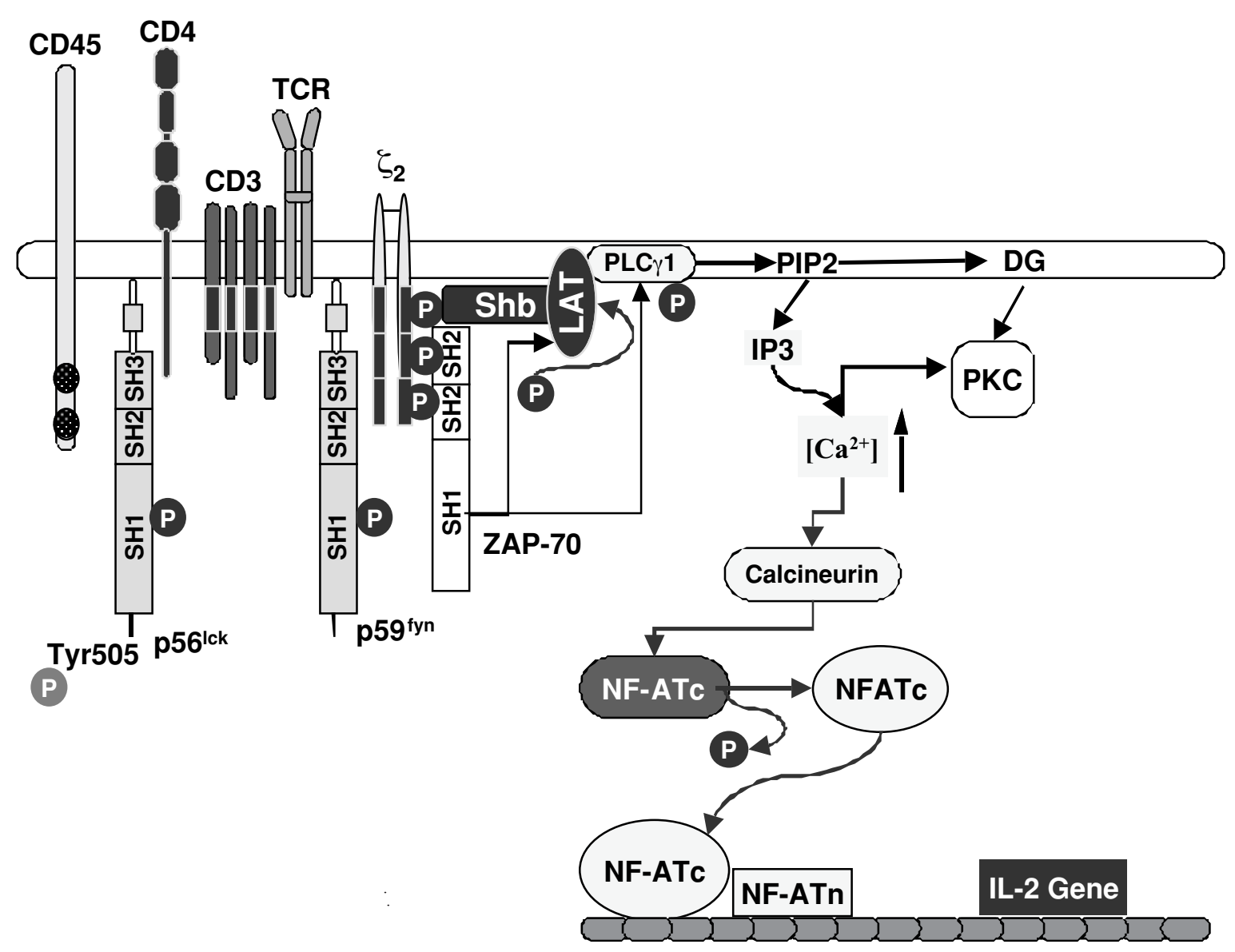

Figure 1. The TCR signaling machinery and activation of PLC $\gamma 1$. The initial signalosome consists of the TCR, the associated CD3/ $\zeta_{2}$ complex, the co-receptor $\mathrm{CD} 4$, the phosphatase CD45, and the srk kinases p56 lck and p59 $9^{f y n}$. The syk kinase ZAP-70 is recruited following phosphorylation of tyrosines located in ITAMs of CD3 and $\xi_{2}$ by srk kinases. See text for details.

The relocalization of signalosomes to receptorassociated scaffolds is crucial for effective signal transduction (Delgado et al., 2000; Harder and Kuhn, 2000; Werlen et al., 2000). Adapter proteins with SH2 domains bind to the phosphorylated $\zeta$ chain. Among these proteins is the "Src homology 2 protein of beta-cells" (Shb), which recruits LAT (Welsh et al., 1998; Zhang et al., 1998), a substrate for ZAP-70 (Figure1). Tyrosine phosphorylation of LAT leads to the recruitment of additional signaling molecules with SH2 motifs (Figures 1 and 2), including the adapter "growth factor receptor-bound protein 2" (Grb2), the phospholipase $\mathrm{C}_{\gamma} 1$ (PLC $\gamma 1$ ), and the p85 subunit of phosphatidylinositol 3-kinase (PI 3-kinase) (Paz et al., 2001; Sommers et al., 2001; Yablonski and Weiss, 2001; Zhang et al., 1998).

Active PLC $\gamma 1$ hydrolyzes phosphotidylinositol biphosphate $\left(\mathrm{PIP}_{2}\right)$, producing diacylglycerol (DAG) and 1,4,5-inositol triphosphate $\left(\mathrm{IP}_{3}\right)$. DAG in turn activates the serine/threonine kinase family of protein kinase $C$ (PKC), while $\mathrm{IP}_{3}$ induces calcium ion $\left(\mathrm{Ca}^{2+}\right)$ mobilization in the cytosol (Corado et al., 1990; May et al., 1986). Thus, ZAP70 amplifies the TCR signal by specifically phosphorylating downstream components such as LAT and PLC $\gamma 1$ (Figures 1 and 2).

In this way, the signalosome expands in molecular complexity and amplifies the TCR initiated signal. Importantly, LAT can also bind proteins that negatively regulate $\mathrm{TCR}$ signaling. The " $\mathrm{SH} 2$ domain-containing hematopoietic phosphotyrosine phosphatase", SHP-1, associates with LAT upon TCR stimulation (Kosugi et al., 2001; Su et al., 2001) and prevents further phosphorylation of the adapter by ZAP-70, suggesting a potential conversion from an "activating" to an "inhibiting" signalosome. Similarly, the "C-terminal src kinase" (Csk) relocalizes to rafts by docking to the transmembrane adapter, Csk-binding protein (Cbp), also known as "phosphoprotein associated with glycosphingolipid-enriched microdomains" (PAG) (Brdicka et al., 2000). In rafts, Csk inhibits src family PTKs by phosphorylating their regulatory tyrosines, and thus blocks TCR-mediated signal transduction (Vang et al., 2001). 


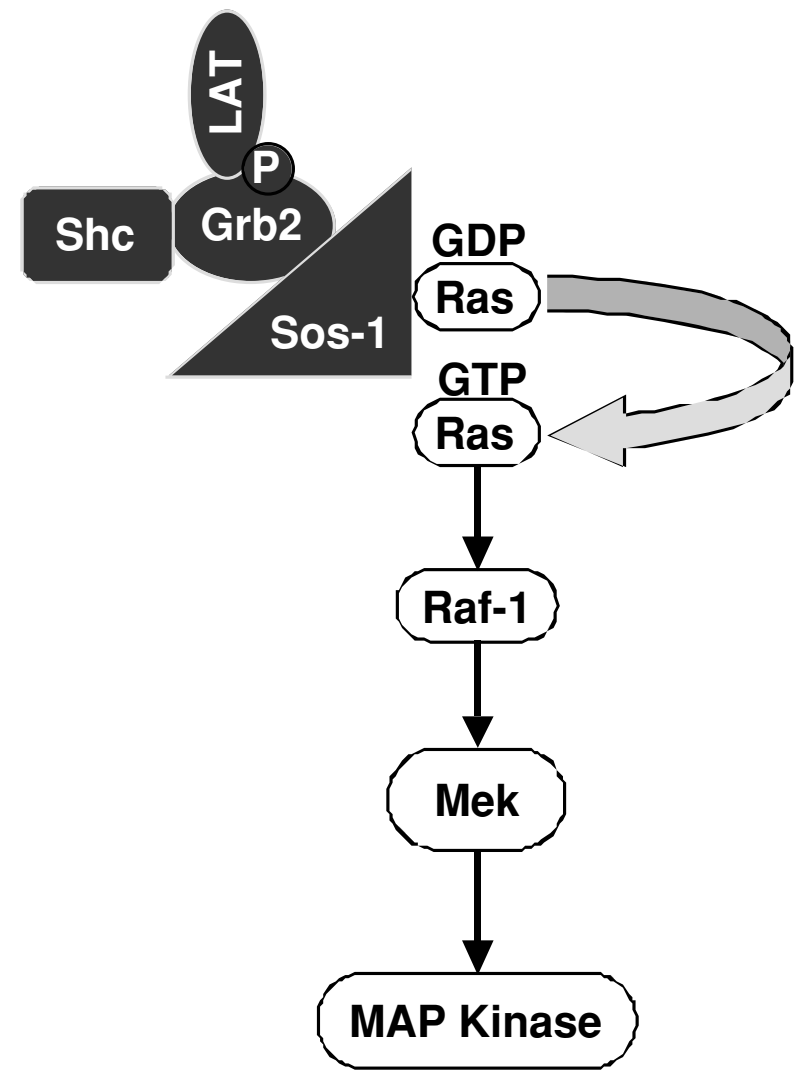

Figure 2. LAT and the MAP kinase signaling pathway. Phosphorylation of LAT by ZAP-70 induces recruitment of multiple adapter proteins and the bifunctional guanine nucleotide exchange factor, Son of sevenless (Sos1), leading to the activation of the MAP kinase signaling pathway. See text for details.

\section{The CD4 coreceptor}

The best-characterized coreceptors, and most important for the discussions presented in this review, are the membrane glycoproteins CD4 and CD8. In mature T cells, the expression of CD4 and CD8 is mutually exclusive. In general, $\mathrm{CD}^{+} \mathrm{T}$ cells respond to antigen presented by $\mathrm{MHC}$ class II molecules, and $\mathrm{CD} 8^{+} \mathrm{T}$ cells respond to $\mathrm{MHC}$ class I-presented antigens (Bierer et al., 1989; Swain, 1983). Therefore, $\mathrm{CD}^{+}$and $\mathrm{CD} 8^{+} \mathrm{T}$ cells are considered to be restricted by $\mathrm{MHC}$ class II and MHC class I, respectively. Importantly, $\mathrm{MHC}$ class restriction is independent of the Th or cytotoxic functions displayed by mature T cells (Krensky et al., 1982; Meuer et al., 1982; Swain, 1981). The correlation between CD4 or CD8 expression and $\mathrm{MHC}$ recognition results from direct interactions between the coreceptors and relatively monomorphic regions of the membrane-proximal, immunoglobulin-like domains of the MHC molecules (Connolly et al., 1990; Gao et al., 1997; Kern et al., 1998; König et al., 1992; König et al., 1995; Salter et al., 1990).

Coreceptors are associated with the TCR/CD3- $\zeta$ complex upon T cell activation. Their presence in the TCR multi-component signaling machine amplifies or modulates the activation signal. Often, their presence is absolutely required, but not sufficient, for productive signaling, i.e., signaling that results in cell cycle progression and effector functions. Interestingly, three-dimensional live cell imaging of fluorescence resonance energy transfer between $\mathrm{CD} 3-\zeta$ and CD4 demonstrates recruitment of CD4 to the CD3- $\zeta$ complex dependent on antigen-stimulation of the TCR (Zal et al., 2002). Importantly, the antigen threshold for T cell activation is affected by the presence of CD4 in the TCR/ CD3 complex. In the presence of CD4, a single MHC class II molecule presenting antigen suffices to induce $\mathrm{Ca}^{2+}$ flux, and 10 class II MHC/antigen complexes cause the formation of an immunological synapse (Irvine et al., 2002). Blocking of CD4 reduces the sensitivity to antigen stimulation by more than three-fold (Irvine et al., 2002).

The structural basis of interactions between CD4 and MHC class II molecules

The proteins encoded by the class II MHC consist of two non-covalently associated integral membrane polypeptide chains, the $\alpha$ and the $\beta$ chains (König et al., 1996). Each polypeptide chain forms two protein domains ( $\alpha 1, \alpha 2$, $\beta 1$, and $\beta 2$ ). The $\alpha 1$ and $\beta 1$ domains are highly polymorphic and combine to form an antigen peptide-binding groove (Brown et al., 1988; Brown et al., 1993). Using a combination of mutational and functional analysis, we identified amino acid residues on MHC class II molecules that mediate the interaction with CD4 (König et al., 1992; König et al., 1995). A major CD4 binding site, forming a short loop exposed on the surface of the class II $\beta 2$ domain, consists of amino acids 134-148 (Cammarota et al., 1992; König et al., 1992). Specifically, glutamic acid 137 is mandatory for mediating the interactions with CD4, and an alanine substitution at this position alone will disrupt all $\mathrm{T}$ cell functions mediated by engagement of CD4 (König et al., 1992). A second interaction site is located within the a2 domain of MHC class II (Gaubin et al., 1999; König et al., 1995). Importantly, both sites are required for mediating interactions with CD4. We have recently reviewed the literature on interactions between $\mathrm{MHC}$ molecules and coreceptors of the TCR (König, 2002).

\section{Functional consequences of CD4 engagement by monoclonal antibodies}

The crystal structure of the exodomains of human CD4 suggests that the membrane proximal domains of CD4 may promote dimerization (Wu et al., 1997). Extraction of CD4 oligomers from freshly isolated T lymphocytes and lymphoid cell lines also indicates that oligomerization may be an intrinsic property of CD4 molecules (Lynch et al., 1999). Many cell surface receptors transduce signals following oligomerization (Papoff et al., 1999; Rodriguez-Frade et al., 1999; White and Tartaglia, 1999). Therefore, a common procedure to test whether CD4 can activate intracellular signaling pathways utilizes crosslinking anti-CD4 antibodies alone or in conjunction with anti-TCR antibodies (Luo and Sefton, 1990; Pallier et al., 1998; Prasad et al., 1993; Ravichandran et al., 1993; Veillette et al., 1989). However, antibody-mediated crosslinking prevents co-localization of CD4 with TCR molecules (Ratcliffe et al., 1992), and does not adequately reflect CD4-mediated signaling induced by engaging $\mathrm{MHC}$ class II during antigen activation. 


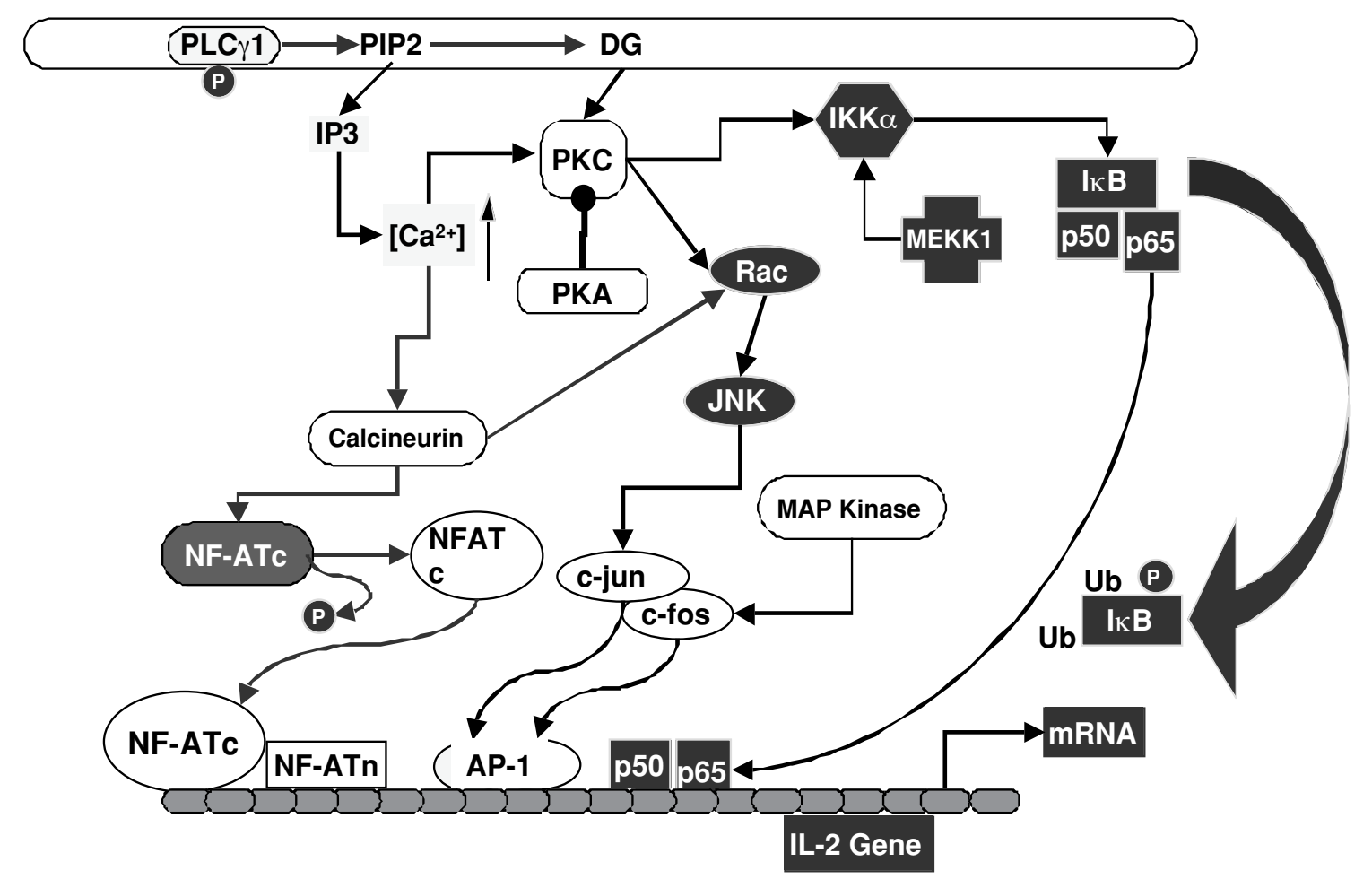

Figure 3. The signaling pathways induced by stimulation of the TCR/CD3/ $\zeta_{2}$ complex mediate translocation of NF-AT, AP-1, and NF- $\mathrm{B} B$ transcription factors to the nucleus, leading to IL-2 gene expression. See text for details.

Ligation of CD4 by anti-CD4 antibodies or the envelope glycoprotein of the human immunodeficiency virus (HIV), gp120, inhibits antigen-dependent and -independent T cell activation (Jabado et al., 1994; Jauliac et al., 1998; Marschner et al., 2002). The inhibition of T cell activation induced by CD4 ligation depends on the cytoplasmic domain of CD4 (Marschner et al., 2002). Binding of these cross-linking ligands decreases the DNA-binding activity of the nuclear transcription factors NF-AT, NF- $\mathrm{B}$, and AP1 , thus preventing IL-2 synthesis (Jabado et al., 1994). These results indicate that ligation of CD4 apart from the TCR/CD3 complex induces negative, regulatory signals that prevent the activation of nuclear factors necessary for IL-2 gene transcription and cell proliferation. Interestingly, memory $\mathrm{CD}^{+} \mathrm{T}$ cells appear to be more susceptible to negative signals transduced via CD4 as their activation can be prevented by both antibody-mediated CD4 ligation and MHC class II molecules on APCs in the absence of antigen (Farber et al., 1995).

Experiments using various monoclonal anti-CD4 antibodies recognizing different epitopes suggested the existence of specific signaling epitopes on CD4 (Milia et al., 1997). Depending on the epitope recognized by a specific monoclonal antibody, different signaling pathways are activated. Also, the simultaneous engagement of nonoverlapping CD4 epitopes can modify the signals from individual epitopes (Milia et al., 1997). These experiments and structure-function analysis of the CD4-MHC class II interaction suggest that $\mathrm{MHC}$ class II molecules bind to a broad region on the membrane-distal domains of CD4 (König et al., 1996), and induce signals via CD4 that differ from those induced by other natural CD4 ligands (e.g., gp120 and IL-16) or monoclonal antibodies. Therefore, we used a dual approach to identify CD4-mediated signals induced by $\mathrm{MHC}$ class II engagement. First, we separated TCR-mediated and CD4-mediated signals by restricting the ability of MHC class II to interact with CD4 during antigen stimulation (Zhou and König, 2003). Second, we avoided antibody-mediated crosslinking, but employed a peptide mimetic to engage the CD4 epitope recognized by MHC class II (Zhou and König, 2003). This peptide binds to CD4 ${ }^{+}$T cells (Shen et al., 1996) and soluble CD4 (Cammarota et al., 1992).

The formation of the immunological synapse

TCR-antigen/MHC interactions initiate the formation of a specialized junction between T cells and APCs, the immunological synapse (Monks et al., 1998). Stimulationand cytoskeleton-dependent processes cluster TCR/CD3 complexes in the center of the synapse, also termed the "central zone of the supramolecular activation cluster" (cSMAC), whereas adhesion molecules such as LFA-1 form a ring surrounding the central area called the peripheral SMAC (pSMAC) (Delon and Germain, 2000; Grakoui et al., 1999). After stimulation of the T cell, CD4 coreceptors are rapidly recruited into the CSMAC, but migrate towards the periphery within a few minutes, while TCR/CD3 complexes stabilize within the central area 


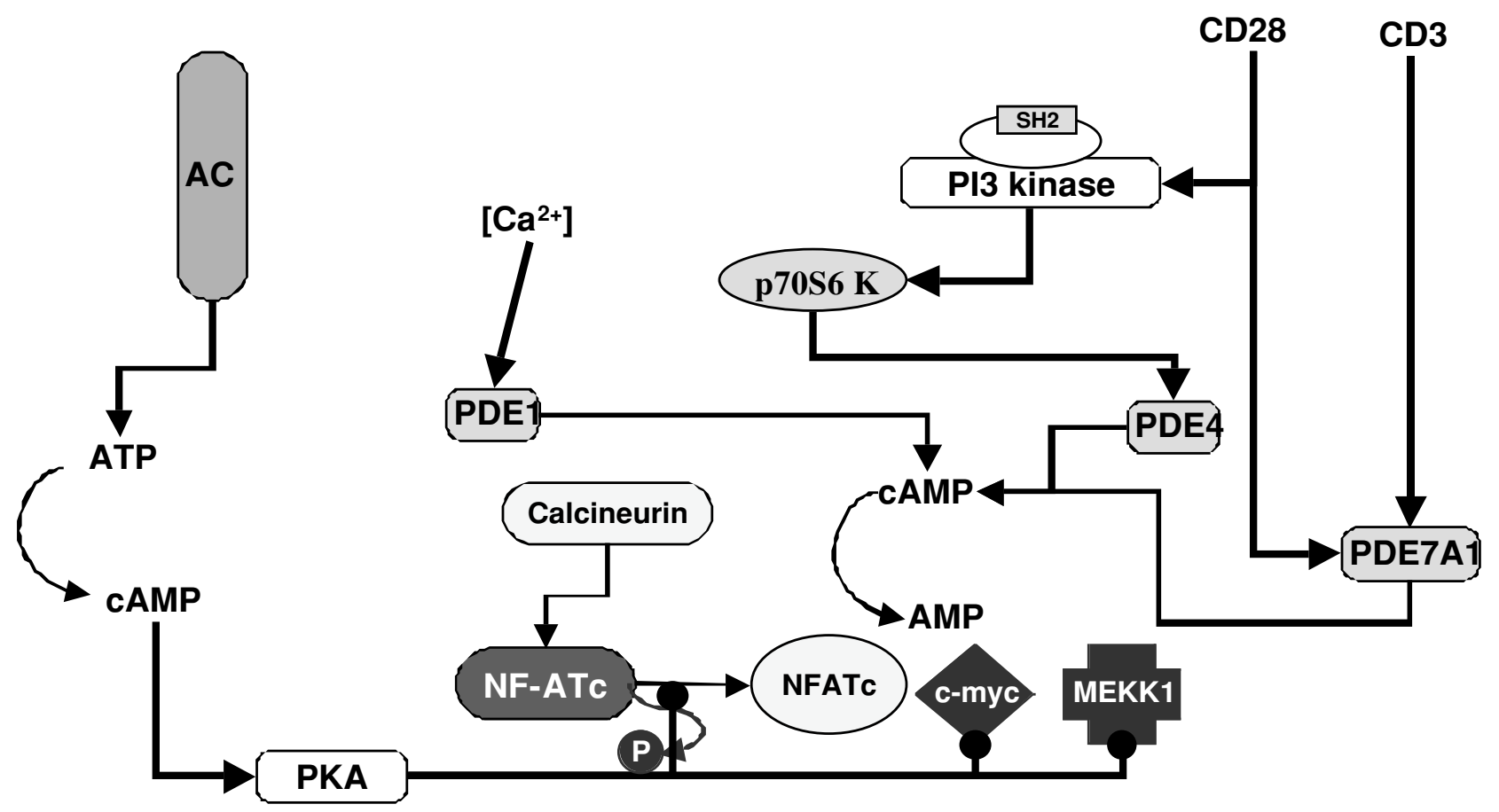

Figure 4. Cyclic AMP exerts multiple regulatory effects on T cell activation and is itself regulated by multiple signaling pathways that activate or block adenylyl cyclase and activate phosphodiesterases. Stimulatory effects are indicated by a line ending in an arrow, whereas inhibitory effects are depicted by a line ending in a filled circle. See also effects of PKA on Raf-1 (Figure 2) and PKC (Figure 3). The overall effect of PKA I activation is inhibition of IL-2 gene expression.

(Krummel et al., 2000). Both CD4 and CD8 associate with the PTK p56 lck, and the efficient transport of p56 lck into the cSMAC is a major function of these coreceptors (Holdorf et al., 2002).

\section{T cell signaling pathways}

One of the earliest antigen-induced signaling events is the mobilization of $\mathrm{Ca}^{2+}$, which is essential for Th cell activation (Wülfing et al., 1997). This second messenger activates several cytosolic enzymes, initiating downstream signaling cascades (Berridge, 1993a). However, antigen stimulation also generates signals through the TCR that antagonize Th cell activation. For example, TCR-mediated signals activate the $3^{\prime}, 5^{\prime}$-cyclic adenosine monophosphate (cAMP)dependent protein kinase, PKA (Laxminarayana and Kammer, 1996; Skalhegg et al., 1992). PKA initiates a signaling pathway that inhibits antigen-induced $T$ cell proliferation and cytokine production (Paliogianni et al., 1993; Vang et al., 2001). Therefore, to achieve full activation of Th cells, TCR-mediated signals must be modified. We have recently identified signaling pathways induced by MHC class II engagement of CD4. These TCR-independent signals participate in the regulation of intracellular concentrations of both $\mathrm{Ca}^{2+}$ and cAMP (Zhou and König, 2003).

\section{Calcium mobilization}

The TCR-induced signal transduction leads to the activation of PLC $\gamma 1$ (Figure 1). Binding of $\mathrm{IP}_{3}$ to its receptor in the membrane of the endoplasmic reticulum induces the release of $\mathrm{Ca}^{2+}$ into the cytosol (Corado et al., 1990). The subsequent increase in intracellular free $\mathrm{Ca}^{2+}$ opens $\mathrm{Ca}^{2+}$ regulated $\mathrm{Ca}^{2+}$ channels in the plasma membrane, inducing additional $\mathrm{Ca}^{2+}$ influx (Berridge, 1993b; Tsien et al., 1982). Intracellular free $\mathrm{Ca}^{2+}$ acts as an essential second messenger for T cell activation (Weiss et al., 1984). Its regulatory effects on $\mathrm{T}$ cell activation are mediated via calmodulin, a $\mathrm{Ca}^{2+}$-binding protein expressed in all eukaryotic cells (Zhang et al., 1998). Effective T cell activation leading to IL-2 secretion requires that intracellular $\mathrm{Ca}^{2+}$ levels be elevated for a period of 1-2 $\mathrm{h}$ (Karttunen and Shastri, 1991; Negulescu et al., 1994). Sustained Ca ${ }^{2+}$ signaling is required for maintaining the transcription factor "Nuclear Factor of Activated T cells" (NFAT) in the nucleus in an active form (Loh et al., 1996; Timmerman et al., 1996). NFAT is a key transcriptional regulator of the IL-2 gene (Rooney et al., 1995) (Figure 3).

$\mathrm{Ca}^{2+}$ signaling is required for various lymphocyte activities, for example cell motility is impeded by increases in $\mathrm{Ca}^{2+}$ (Donnadieu et al., 1994; Negulescu et al., 1996). Increases in $\mathrm{Ca}^{2+}$ cause changes in the cytoskeletal structure (Wülfing and Davis, 1998), induce cell death in immature thymocytes (Andjelic et al., 1993), differentiation (Sloan-Lancaster et al., 1997), and activation (Gearing et al., 1985). Thus, a single second messenger can elicit multiple cellular responses. The type of response induced may depend on the amplitude, duration, and temporal fluctuations of $\mathrm{Ca}^{2+}$ mobilization. For example, activation of NF- $\mathrm{KB}$ is induced by high levels of $\mathrm{Ca}^{2+}$, because of this 


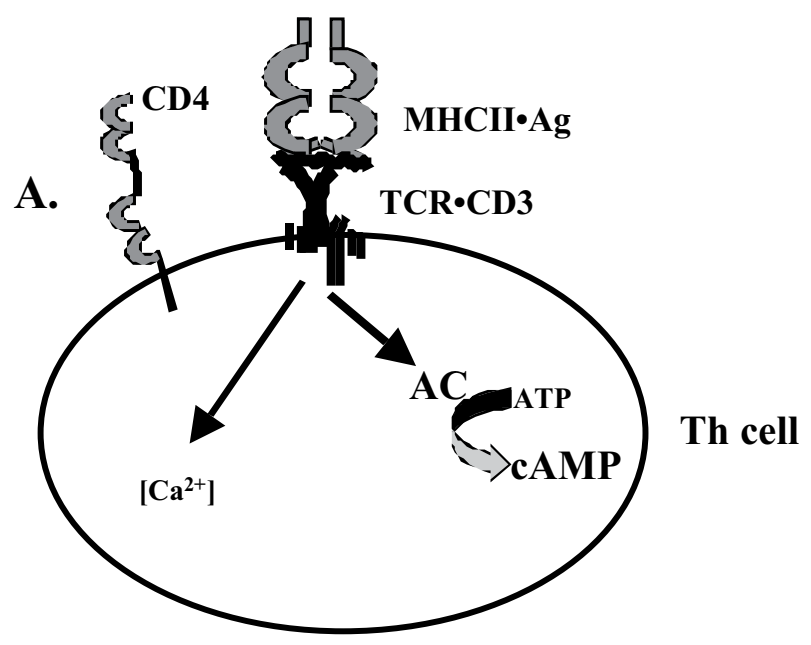

B.

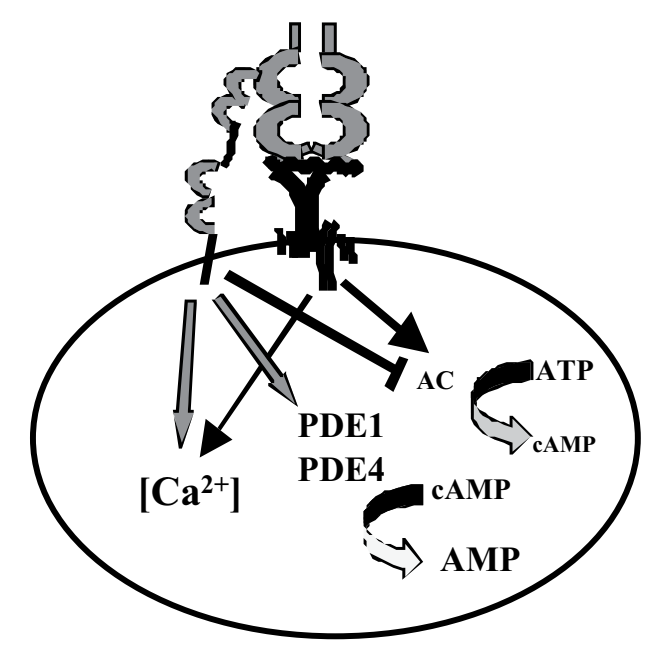

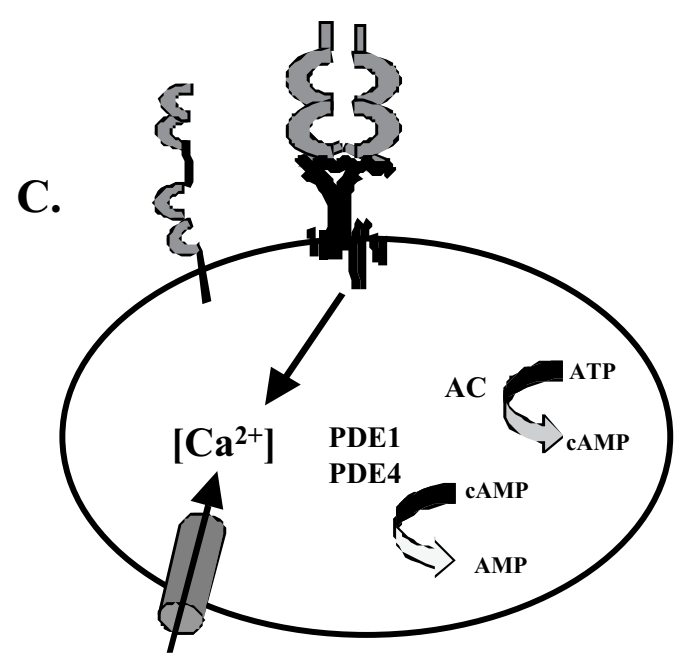

Figure 5. Regulation of intracellular $\mathrm{Ca}^{2+}$ and cAMP levels by TCR and CD4 signaling. A. Binding of the TCR to the antigen/MHC class II ligand induces Ca $2+$ mobilization and activates adenylyl cyclase, raising intracellular cAMP levels. B. CD4 is recruited to the signalosome and binds to MHC class II. CD4 signaling increases $\mathrm{Ca}^{2+}$ mobilization, activates cAMP phosphodiesterases, and inhibits adenylyl cyclase. The intracellular concentration of cAMP drops below resting levels. C. CD4 is released from the central area of the immunological synapse. $\mathrm{Ca}^{2+}$-gated membrane $\mathrm{Ca}^{2+}$ channels maintain a sustained high level of intracellular $\mathrm{Ca}^{2+}$.

transcription factor's low $\mathrm{Ca}^{2+}$ sensitivity. In contrast, even low elevations of $\mathrm{Ca}^{2+}$ levels, if maintained over a prolonged period of time, selectively activate NFAT, because NFAT is highly sensitive to $\mathrm{Ca}^{2+}$ but is rapidly inactivated after $\mathrm{Ca}^{2+}$ removal (Dolmetsch et al., 1997).

\section{Cyclic AMP, adenylyl cyclases, and cyclic nucleotide phosphodiesterases}

Cyclic AMP has been defined as an intracellular second messenger to a wide variety of hormones and neurotransmitters. In T cells, numerous studies have shown that elevated cAMP levels antagonize T cell activation. In addition to inhibiting T cell proliferation (Lingk et al., 1990), cAMP suppresses the production of IL-2 and IFN- $\gamma$ in activated Th cells (Zidek, 1999). Opposite effects on IL-5 production from activated Th cells have been observed in different studies (Staples et al., 2000). TCR signaling alone elevates adenylyl cyclase (AC) activity and intracellular CAMP (Feuerstein et al., 1996). Importantly, TCRindependent signals induced by CD4 engagement regulate
cAMP levels (Zhou and König, 2003).

In T cells, the cAMP level is controlled by two types of enzymes: ACs and cyclic nucleotide phosphodiesterases (PDEs). ACs catalyze the production of cAMP from ATP, whereas PDEs control the rate of CAMP degradation to AMP. At least eleven families of PDEs have been classified by their primary sequences, substrate specificities, susceptibility to selective inhibitors, and tissue location (Manganiello et al., 1995; Soderling and Beavo, 2000). Among them, PDE families 1,3,4, and 7 have been found in T cells (Ekholm et al., 1997; Giembycz et al., 1996; Hurwitz et al., 1990). The activity of each of these four families is controlled by distinct mechanisms. The PDE1 family is stimulated by $\mathrm{Ca}^{2+} /$ calmodulin (Charbonneau et al., 1991). The PDE3 family is inhibited by cyclic GMP (Tang et al., 1997). Activation of the PDE4 family has been linked to different pathways. In 3T3-F442A fibroblasts, PDE4 activity is induced by stimulation of p70S6 kinase (Mackenzie et al., 1998), whereas in FDCP2 myeloid cells, PDE4 is activated via MAP kinase-dependent pathways 
(Ahmad et al., 1999). In T cells, CD3 and CD28-mediated signals activate the PDE7 family (Li et al., 1999).

Elevation of cAMP has long been regarded as inhibitory to $T$ cell activation (Figures 3 and 4). However, inhibition of basal PKA I activity leads to decreased TCR-triggered IL-2 production (Sugiyama et al., 1997; Zhou and König, 2003). Also, purified human T cells stimulated by mitogens transiently up-regulate $A C$ and PDE activities with different kinetics for different PDE isozymes (Kanda and Watanabe, 2001). Both observations suggest a requirement of cAMP for $T$ cell activation. We have recently demonstrated that cAMP is required for cell cycle progression and cytokine gene expression following antigenic activation of Th cells (Zhou and König, 2003). Thus, a precise kinetic regulation of the intracellular cAMP concentration is required for Th cell activation.

\section{Cyclic AMP-dependent kinase}

The second messenger, cAMP, activates a class of cyclic nucleotide-gated ion channels. It also directly activates the guanine-nucleotide-exchange factors Epac1 and Epac2, which are able to activate Rap1 by promoting its release of GDP and binding to GTP (De Rooij et al., 1998; Kawasaki et al., 1998). Rap is a small Ras-like GTPase that can suppress the oncogenic transformation of cells by Ras. It is also involved in other cellular activities, including cell differentiation, $\mathrm{T}$ cell anergy, and platelet activation (Boussiotis et al., 1997; Franke et al., 1997; York et al., 1998).

The cAMP-dependent protein kinase, PKA, is the principal intracellular cAMP receptor (Beebe, 1994; Walsh and Van Patten, 1994). In the absence of cAMP, PKA is an enzymatically inactive, tetrameric holoenzyme, consisting of two catalytic subunits and two regulatory subunits. The cooperative binding of four cAMP molecules to two sites on each regulatory subunit drastically decreases the binding affinity between regulatory and catalytic subunits, and induces dissociation into dimeric regulatory and two monomers of catalytic subunits (Doskeland et al., 1993). Once freed from the regulatory subunits, the catalytic subunits display serine/threonine kinase activity (Houge et al., 1990).

PKA I, but not PKA II, mediates the inhibitory role of CAMP on T cell proliferation induced by TCR signaling (Aukrust et al., 1999; Skalhegg et al., 1992). PKA I antagonizes $T$ cell activation at multiple levels (Chen and Rothenberg, 1994; Ramstad et al., 2000; Van Oirschot et al., 2001; Vang et al., 2001), one of which is to activate the protein tyrosine kinase, Csk (Vang et al., 2001). Csk inhibits Lck activity(Abraham and Veillette, 1990). By inhibiting Lck, PKA I can diminish $T$ cell activation at the initiation stage. This suggests that at the early stage of $T$ cell activation, PKA I activity needs to be restricted. PKA I also phosphorylates Raf-1 to block the MAP kinase pathway (Ramstad et al., 2000) (Figures 2 and 3). In the nucleus, activation of PKA prevents stable protein-DNA interactions at the NF-KB, NFAT, and AP1 binding sites of the IL-2 enhancer (Chen and Rothenberg, 1994) (Figures 3 and 4). In addition, PKA I activity also inhibits cyclin D3 expression and induces the cyclin-dependent kinase inhibitor p2 $7^{\text {kip } 1}$ (Van Oirschot et al., 2001). For T cells to enter the S phase of the cell cycle, D-type cylins, including cyclin D3, are synthesized during the $\mathrm{G}_{1}$ phase (Boonen et al., 1999). These cyclins can bind to cyclin-dependent kinase (Cdk) and form an active kinase complex that phosphorylates and inactivates retinoblastoma protein, $\mathrm{pRb}$ (Weinberg, 1995). Inactivation of $p R b$ then allows cells to pass through the late $\mathrm{G}_{1}$ phase restriction point and enter the $S$ phase. However, cyclin D/Cdk complexes can associate with the Cdk inhibitor p27 ${ }^{k i p 1}$, thus rendered inactive (Firpo et al., 1994; Nourse et al., 1994). Therefore, in addition to induction of cyclin D, downregulation of p27 kip1 is also required for the initiation of $\mathrm{T}$ cell proliferation (Boonen et al., 1999; Firpo et al., 1994; Nourse et al., 1994). Hence, inhibition of cyclin D3 expression and induction of p2 $7^{\text {kip } 1}$ by PKA I both block T cell cycle progression. Little is known about the distribution of PKA I in activated T cells. The only study reported so far demonstrated co-localization of the PKA I holoenzyme with the TCR/CD3 complex in human peripheral blood T cells after crosslinking with antiCD3 mAb for 30 min (Skalhegg et al., 1994).

\section{Functional consequences of CD4 engagement by MHC class II}

Interactions between CD4 and MHC class II increase antigen-induced Th cell proliferation and cytokine production. Initially, it was thought that CD4 functioned as an adhesion molecule, enhancing contact between Th cells and APCs (Gay et al., 1987). However, CD4 and MHC class II interact with extremely low affinity (Weber and Karjalainen, 1993; Xiong et al., 2001), and soluble CD4 does not affect the binding of soluble antigen/MHC class II complexes to immobilized TCR (Xiong et al., 2001). Furthermore, CD4-MHC class II interactions do not increase the binding avidity between Th cells and APCs (Hamad et al., 1998; Metz et al., 1997; Zhou and König, 2003). Thus, an adhesive effect of CD4 is unlikely, and the major function of CD4 may be its active participation in Th cell signaling (Sleckman et al., 1991; Zhou and König, 2003).

\section{Role of CD4 in modulating T cell signal transduction}

Experiments in our laboratory suggest that CD4-mediated signals facilitate Th cell activation by two mechanisms (Figure 5). First, engagement of CD4 by MHC class II induces increased $\mathrm{Ca}^{2+}$ mobilization from intracellular stores. This CD4-induced $\mathrm{Ca}^{2+}$ signal synergizes with the TCR-mediated $\mathrm{Ca}^{2+}$ signal, thereby allowing the sustained activation of $\mathrm{Ca}^{2+}$-regulated membrane $\mathrm{Ca}^{2+}$ channels and promoting a sustained rise in intracellular free $\mathrm{Ca}^{2+}$ (Zhou and König, 2003). A long-lasting elevation of $\mathrm{Ca}^{2+}$ is required for effective Th cell activation (Rabinowitz et al., 1996; Wulfing et al., 1997). Second, CD4 signaling counteracts the TCR-mediated increases in cAMP (Zhou and König, 2003). The CD4-mediated signals activate cAMP PDEs and inhibit AC. TCR signaling in the absence of additional, modifying signals results in the accumulation of cAMP in the cytosol and thus, in partial Th cell activation without the induction of efficient proliferation and cytokine production (Feuerstein et al., 1996; Zhou and König, 2003). Therefore, signals induced by MHC class II engagement 
of CD4 are critical for successful Th cell activation.

An important characteristic for effective regulation of intracellular CAMP by CD4 signaling is the temporal and spatial sequence of CD4 localization in the signaling synapse. Recruitment of CD4 depends on binding of the TCR to its specific antigen/MHC class II ligand (Krummel et al., 2000). Thus, an initial TCR-mediated increase in AC activity may be countered by CD4-mediated AC inhibition and PDE activation to promote early T cell activation events. Exclusion of CD4 from the central TCR cluster to the periphery of the signaling synapse within a few min after the initial $\mathrm{Ca}^{2+}$ signal (Krummel et al., 2000) may then remove the block on cAMP increases to promote proliferation and cytokine production.

The activities of ACs are controlled by hormones, neurotransmitters, chemotactic transducers, and other molecules. A common mechanism to inhibit $A C$ activity is through the activation of $G_{i}$ proteins (e.g., $G_{i 1}, G_{i 2}$, and $G_{i 3}$ ), which are coupled to receptors for effector molecules. Members of the $G_{i}$ family of proteins positively regulate $T$ cell activation (Lippert et al., 2000). A 32-kDa GTP-binding protein associates with CD4 and CD8 in human T cell lines (Telfer and Rudd, 1991). Therefore, inhibition of AC by CD4$\mathrm{MHC}$ class II engagement may be mediated via $G_{i}$ proteins. CD4 may serve as a docking protein, carrying $G_{i}$ proteins to the signaling synapse in activated Th cells, similar to the mechanism by which CD4 promotes p56 lck function (Holdorf et al., 2002).

Therefore, we propose that transduction of costimulatory signals induced by $\mathrm{MHC}$ class II engagement represent a major function of the CD4 coreceptor and that CD4mediated signals participate in the precise regulation of intracellular levels of cAMP following $T$ cell stimulation.

\section{Role of CD4 in regulating $T$ cell homeostasis}

We have recently reported that coreceptor interactions with $\mathrm{MHC}$ molecules also regulate peripheral T cell homeostasis and the survival of naïve T cells in the absence of antigenic stimulation (König, 2002; König et al., 2002). We discovered this function of CD4 in a transgenic mouse strain that we generated for the purpose of elucidating the role of CD4 engagement by MHC class II in thymic selection and peripheral activation of Th cells. These transgenic mice express mutant MHC class II molecules defective in their ability to engage CD4 (Gilfillan et al., 1998). Despite the inability of the mutant MHC class II expressed on thymic epithelial cells to interact with CD4, positive thymic selection into the CD4 lineage proceeds, and $\mathrm{CD}^{+}$thymocytes mature. However, levels of single-positive CD4 ${ }^{+}$ thymocytes in these mice are less than one third of those in normal mice. Furthermore, peripheral, naïve CD4 ${ }^{+} \mathrm{T}$ cells undergo apoptosis at an approximately three-fold higher rate in mutant $\mathrm{MHC}$ class II transgenic mice than do CD4 lineage cells in normal mice (Maroto et al., 1999). The increased frequency of apoptotic cells is due to a lack of CD4-MHC class II interactions in peripheral lymphoid organs, because naïve $\mathrm{CD}^{+} \mathrm{T}$ cells from normal mice adoptively transferred into mutant $\mathrm{MHC}$ class II transgenic hosts meet the same fate as do endogenous Th cells (Shen and König, 2001). Similarly, CD4-deficient Thelper lineage cells are apoptosis-prone, and fail to survive after adoptive transfer into irradiated hosts (Strong et al., 2001). Thus, CD4 lineage T cells require CD4-MHC class II interactions for efficient positive selection in the thymus and for maintenance of homeostasis in the periphery. Following the selection in the thymus for cells with TCRs that appropriately recognize self-MHC/peptide ligands, a peripheral recertification process enhances the stringency for proper matching between TCR restriction and coreceptor recognition of MHC (König et al., 2002). This process depends on signals through CD4 (Shen and König, 2001; Strong et al., 2001).

At the present time, we do not know whether the defect in peripheral Th cell homeostasis in the absence of CD4 engagement by MHC class II is related to an impaired regulation of intracellular cAMP levels. However, this is an attractive hypothesis and future research is targeted towards answering this question.

\section{Outlook}

The receptors that induce $T$ cell signaling and the intracellular proteins mediating specific signal transduction pathways have been mostly identified. It is evident that signalosomes in T cells differ in composition depending on the extracellular signal received and the requirements of the stimulated cell. Depending on the level of participation of coreceptors in the induction and modulation of signaling pathways, the composition of established signalosomes may change over time in order to permit the fine-tuning of effector signaling pathways. Future research will focus on determining the kinetics of assembly, the dynamics of composition, and the compartmentalization of components of signalosomes induced during $T$ cell activation. An important aspect will also be to define the interactions between different signaling pathways.

A clear understanding of Th cell signaling will provide a blueprint for the rationale intervention in multiple immune effector functions. Th cells promote adaptive immune responses against infective microorganisms and tumor cells, but also hamper tissue and organ transplantation. In addition, improper activation of Th cells can cause autoimmune diseases. Thus, targeting coreceptor-induced signaling pathways could improve vaccine development and therapeutic approaches to infectious diseases and cancer.

\section{Acknowledgements}

This work was supported in part by grants from the American Heart Association and the National Science Foundation. W.Z. acknowledges support from the McLaughlin Fellowship Fund, the American Foundation for Aging Research, the Christina Fleischmann Foundation, and the Association for Women in Science.

\section{References}

Abraham, N. and Veillette, A. 1990. Activation of p56 lck through mutation of a regulatory carboxy-terminal tyrosine residue requires intact sites of autophosphorylation and myristylation. Mol Cell Biol 10: 5197-5206.

Ahmad, F., Gao, G., Wang, L.M., Landstrom, T.R., 
Degerman, E., Pierce, J.H., and Manganiello, V.C. 1999. IL-3 and IL-4 activate cyclic nucleotide phosphodiesterases 3 (PDE3) and 4 (PDE4) by different mechanisms in FDCP2 myeloid cells. J. Immunol. 162: 4864-4875.

Andjelic, S., Jain, N., and Nikolic-Zugic, J. 1993. Immature thymocytes become sensitive to calcium-mediated apoptosis with the onset of CD8, CD4, and the T cell receptor expression: a role for bcl-2? J Exp Med 178: 1745-1751.

Aukrust, P., Aandahl, E.M., Skalhegg, B.S., Nordoy, I., Hansson, V., Tasken, K., Froland, S.S., and Muller, F. 1999. Increased activation of protein kinase A type I contributes to the $T$ cell deficiency in common variable immunodeficiency. J Immunol 162: 1178-1185.

Beebe, S.J. 1994. The cAMP-dependent protein kinases and cAMP signal transduction. Semin Cancer Biol 5: 285294.

Berridge, M.J. 1993a. Cell signalling. A tale of two messengers. Nature 365: 388-389.

Berridge, M.J. 1993b. Inositol trisphosphate and calcium signalling. Nature 361: 315-325.

Bierer, B.E., Sleckman, B.P., Ratnofsky, S.E., and Burakoff, S.J. 1989. The biologic roles of CD2, CD4, and CD8 in Tcell activation. Annu Rev Immunol 7: 579-599.

Bommhardt, U., Scheuring, Y., Bickel, C., Zamoyska, R., and Hunig, T. 2000. MEK activity regulates negative selection of immature $\mathrm{CD} 4^{+} \mathrm{CD} 8^{+}$thymocytes. J Immunol 164: 2326-2337.

Boonen, G.J., Van Dijk, A.M., Verdonck, L.F., Van Lier, R.A., Rijksen, G., and Medema, R.H. 1999. CD28 induces cell cycle progression by IL-2-independent down-regulation of p2 $7^{k i p 1}$ expression in human peripheral T lymphocytes. Eur J Immunol 29: 789-798.

Boussiotis, V.A., Freeman, G.J., Berezovskaya, A., Barber, D.L., and Nadler, L.M. 1997. Maintenance of human T cell anergy: blocking of IL-2 gene transcription by activated Rap1. Science 278: 124-128.

Brdicka, T., Pavlistova, D., Leo, A., Bruyns, E., Korinek, V., Angelisova, P., Scherer, J., Shevchenko, A., Hilgert, I., Cerny, J., Drbal, K., Kuramitsu, Y., Kornacker, B., Horejsi, V., and Schraven, B. 2000. Phosphoprotein associated with glycosphingolipid-enriched microdomains (PAG), a novel ubiquitously expressed transmembrane adaptor protein, binds the protein tyrosine kinase csk and is involved in regulation of T cell activation. J Exp Med 191: 1591-1604.

Brocker, T. 1999. The role of dendritic cells in T cell selection and survival. Journal of Leukocyte Biology. 66: 331-335.

Brown, J.H., Jardetzky, T., Saper, M.A., Samraoui, B., Bjorkman, P.J., and Wiley, D.C. 1988. A hypothetical model of the foreign antigen binding site of class II histocompatibility molecules. Nature 332: 845-850.

Brown, J.H., Jardetzky, T.S., Gorga, J.C., Stern, L.J., Urban, R.G., Strominger, J.L., and Wiley, D.C. 1993. Threedimensional structure of the human class II histocompatibility antigen HLA-DR1. Nature 364: 33-39.

Brugnera, E., Bhandoola, A., Cibotti, R., Yu, Q., Guinter, T.I., Yamashita, Y., Sharrow, S.O., and Singer, A. 2000. Coreceptor reversal in the thymus: signaled $\mathrm{CD}^{+} 8^{+}$ thymocytes initially terminate CD8 transcription even when differentiating into CD8 ${ }^{+} \mathrm{T}$ cells. Immunity 13: 5971.

Bushell, A., Morris, P.J., and Wood, K.J. 1995. Transplantation tolerance induced by antigen pretreatment and depleting anti-CD4 antibody depends on $\mathrm{CD}^{+} \mathrm{T}$ cell regulation during the induction phase of the response. Eur. J. Immunol. 25: 2643-2649.

Cammarota, G., Scheirle, A., Takacs, B., Doran, D.M., Knorr, R., Bannwarth, W., Guardiola, J., and Sinigaglia, F. 1992. Identification of a CD4 binding site on the beta 2 domain of HLA-DR molecules. Nature 356: 799-801.

Capone, M., Romagnoli, P., Beermann, F., Macdonald, H.R., and Van Meerwijk, J.P. 2001. Dissociation of thymic positive and negative selection in transgenic mice expressing major histocompatibility complex class I molecules exclusively on thymic cortical epithelial cells. Blood 97: 1336-1342.

Chan, A.C., Irving, B.A., Fraser, J.D., and Weiss, A. 1991. The zeta chain is associated with a tyrosine kinase and upon T-cell antigen receptor stimulation associates with ZAP-70, a 70-kDa tyrosine phosphoprotein. Proc Natl Acad Sci U S A 88: 9166-9170.

Charbonneau, H., Kumar, S., Novack, J.P., Blumenthal, D.K., Griffin, P.R., Shabanowitz, J., Hunt, D.F., Beavo, J.A., and Walsh, K.A. 1991. Evidence for domain organization within the $61-\mathrm{kDa}$ calmodulin-dependent cyclic nucleotide phosphodiesterase from bovine brain. Biochemistry 30: 7931-7940.

Chen, D. and Rothenberg, E.V. 1994. Interleukin 2 transcription factors as molecular targets of cAMP inhibition: delayed inhibition kinetics and combinatorial transcription roles. J Exp Med 179: 931-942.

Chidgey, A.P. and Boyd, R.L. 2001. Thymic stromal cells and positive selection. APMIS 109: 481-492.

Connolly, J.M., Hansen, T.H., Ingold, A.L., and Potter, T.A. 1990. Recognition by CD8 on cytotoxic T lymphocytes is ablated by several substitutions in the class I alpha 3 domain: CD8 and the T-cell receptor recognize the same class I molecule. Proc Natl Acad Sci USA 87: 2137-2141.

Corado, J., Le Deist, F., Griscelli, C., and Fischer, A. 1990. Inositol 1,4,5-trisphosphate- and arachidonic acid-induced calcium mobilization in $\mathrm{T}$ and $\mathrm{B}$ lymphocytes. Cell Immunol 126: 245-254.

Datta, S.K., Kaliyaperumal, A., Mohan, C., and DesaiMehta, A. 1997. T helper cells driving pathogenic antiDNA autoantibody production in lupus: nucleosomal epitopes and CD40 ligand signals. Lupus 6: 333-336.

De Aos, I., Metzger, M.H., Exley, M., Dahl, C.E., Misra, S., Zheng, D., Varticovski, L., Terhorst, C., and Sancho, J. 1997. Tyrosine phosphorylation of the CD3-epsilon subunit of the $T$ cell antigen receptor mediates enhanced association with phosphatidylinositol 3-kinase in Jurkat T cells. J Biol Chem 272: 25310-25318.

De Rooij, J., Zwartkruis, F.J., Verheijen, M.H., Cool, R.H., Nijman, S.M., Wittinghofer, A., and Bos, J.L. 1998. Epac is a Rap1 guanine-nucleotide-exchange factor directly activated by cyclic AMP. Nature 396: 474-477.

Delgado, P., Fernandez, E., Dave, V., Kappes, D., and Alarcon, B. 2000. CD3delta couples T-cell receptor signalling to ERK activation and thymocyte positive selection. Nature 406: 426-430.

Delon, J. and Germain, R.N. 2000. Information transfer at 
the immunological synapse. Curr Biol 10: R923-933.

Diepolder, H.M., Jung, M.C., Keller, E., Schraut, W., Gerlach, J.T., Gruner, N., Zachoval, R., Hoffmann, R.M., Schirren, C.A., Scholz, S., and Pape, G.R. 1998. A vigorous virus-specific $\mathrm{CD}^{+}{ }^{+} \mathrm{T}$ cell response may contribute to the association of HLA-DR13 with viral clearance in hepatitis B. Clin. Exp. Immunol. 113: 244251.

Dolmetsch, R.E., Lewis, R.S., Goodnow, C.C., and Healy, J.I. 1997. Differential activation of transcription factors induced by $\mathrm{Ca}^{2+}$ response amplitude and duration. Nature 386: 855-858.

Donnadieu, E., Bismuth, G., and Trautmann, A. 1994. Antigen recognition by helper $T$ cells elicits a sequence of distinct changes of their shape and intracellular calcium. Curr Biol 4: 584-595.

Doskeland, S.O., Maronde, E., and Gjertsen, B.T. 1993. The genetic subtypes of cAMP-dependent protein kinase-functionally different or redundant? Biochim Biophys Acta 1178: 249-258.

Ekholm, D., Hemmer, B., Gao, G., Vergelli, M., Martin, R., and Manganiello, V. 1997. Differential expression of cyclic nucleotide phosphodiesterase 3 and 4 activities in human T cell clones specific for myelin basic protein. J. Immunol. 159: $1520-1529$.

Elder, M.E., Skoda-Smith, S., Kadlecek, T.A., Wang, F., Wu, J., and Weiss, A. 2001. Distinct T cell developmental consequences in humans and mice expressing identical mutations in the DLAARN motif of ZAP-70. J Immunol 166: 656-661.

Farber, D.L., Luqman, M., Acuto, O., and Bottomly, K. 1995. Control of memory CD4 T cell activation: MHC class II molecules on APCs and CD4 ligation inhibit memory but not naive CD4 T cells. Immunity 2: 249-259.

Feuerstein, N., Firestein, R., Aiyar, N., He, X., Murasko, D., and Cristofalo, V. 1996. Late induction of CREB/ATF binding and a concomitant increase in cAMP levels in T and $B$ lymphocytes stimulated via the antigen receptor. J. Immunol. 156: 4582-4593.

Firpo, E.J., Koff, A., Solomon, M.J., and Roberts, J.M. 1994. Inactivation of a Cdk2 inhibitor during interleukin 2induced proliferation of human T lymphocytes. Mol Cell Biol 14: 4889-4901.

Franke, B., Akkerman, J.W., and Bos, J.L. 1997. Rapid $\mathrm{Ca}^{2+}$-mediated activation of Rap1 in human platelets. Embo J 16: 252-259.

Gao, G.F., Tormo, J., Gerth, U.C., Wyer, J.R., Mcmichael, A.J., Stuart, D.I., Bell, J.I., Jones, E.Y., and Jakobsen, B.K. 1997. Crystal structure of the complex between human CD8 alpha alpha and HLA-A2. Nature 387: 630634.

Gaubin, M., Houlgatte, R., Dettin, M., Scarinci, C., Martin, M., Guardiola, J., Di Bello, C., and Piatier-Tonneau, D. 1999. Definition of the alpha 2 region of HLA-DR molecules involved in CD4 binding. Hum Immunol 60: 273-281.

Gay, D., Maddon, P., Sekaly, R., Talle, M.A., Godfrey, M., Long, E., Goldstein, G., Chess, L., Axel, R., Kappler, J., and Marrack, P. 1987. Functional interaction between human T-cell protein CD4 and the major histocompatibility complex HLA-DR antigen. Nature 328: 626-629.

Gearing, A.J., Wadhwa, M., and Perris, A.D. 1985. Interleukin 2 stimulates $T$ cell proliferation using a calcium flux. Immunol Lett 10: 297-302.

Germain, R.N. 1994. MHC-dependent antigen processing and peptide presentation: providing ligands for $\mathrm{T}$ lymphocyte activation. Cell 76: 287-299.

Germain, R.N. 2002. T-cell development and the CD4-CD8 lineage decision. Nature Rev Immunol 2: 309-322.

Giembycz, M.A., Corrigan, C.J., Seybold, J., Newton, R., and Barnes, P.J. 1996. Identification of cyclic AMP phosphodiesterases 3, 4 and 7 in human $\mathrm{CD}^{+}$and $\mathrm{CD}^{+}$ T-lymphocytes: role in regulating proliferation and the biosynthesis of interleukin-2. Br. J. Pharmacol. 118: 19451958.

Gilfillan, S., Shen, X., and König, R. 1998. Selection and function of $\mathrm{CD}^{+} \mathrm{T}$ lymphocytes in transgenic mice expressing mutant MHC class II molecules deficient in their interaction with CD4. J Immunol 161: 6629-6637.

Gong, Q., Jin, X., Akk, A.M., Foger, N., White, M., Gong, G., Wardenburg, J.B., and Chan, A.C. 2001. Requirement for tyrosine residues 315 and 319 within zeta chainassociated protein 70 for T cell development. J Exp Med 194: 507-518.

Grakoui, A., Bromley, S.K., Sumen, C., Davis, M.M., Shaw, A.S., Allen, P.M., and Dustin, M.L. 1999. The immunological synapse: a molecular machine controlling T cell activation. Science 285: 221-227.

Hamad, A.R., O'herrin, S.M., Lebowitz, M.S., Srikrishnan, A., Bieler, J., Schneck, J., and Pardoll, D. 1998. Potent T cell activation with dimeric peptide-major histocompatibility complex class II ligand: the role of CD4 coreceptor. J. Exp. Med. 188: 1633-1640.

Harder, T. and Kuhn, M. 2000. Selective accumulation of raft-associated membrane protein LAT in T cell receptor signaling assemblies. J Cell Biol 151: 199-208.

Harder, T. and Kuhn, M. 2001. Immunoisolation of TCR signaling complexes from Jurkat $T$ leukemic cells. Sci STKE 2001: PL1.

Hogquist, K.A. 2001. Signal strength in thymic selection and lineage commitment. Curr Opin Immunol 13: 225231.

Holdorf, A.D., Lee, K.H., Burack, W.R., Allen, P.M., and Shaw, A.S. 2002. Regulation of Lck activity by CD4 and CD28 in the immunological synapse. Nature Immunol. 3: 259-264.

Houge, G., Steinberg, R.A., Ogreid, D., and Doskeland, S.O. 1990. The rate of recombination of the subunits (RI and $\mathrm{C}$ ) of cAMP-dependent protein kinase depends on whether one or two cAMP molecules are bound per RI monomer. J Biol Chem 265: 19507-19516.

Hurwitz, R.L., Hirsch, K.M., Clark, D.J., Holcombe, V.N., and Hurwitz, M.Y. 1990. Induction of a calcium/ calmodulin-dependent phosphodiesterase during phytohemagglutinin-stimulated lymphocyte mitogenesis. J. Biol. Chem. 265: 8901-8907.

Irvine, D.J., Purbhoo, M.A., Krogsgaard, M., and Davis, M.M. 2002. Direct observation of ligand recognition by $T$ cells. Nature 419: 845-849.

Iwashima, M., Irving, B.A., Van Oers, N.S., Chan, A.C., 
and Weiss, A. 1994. Sequential interactions of the TCR with two distinct cytoplasmic tyrosine kinases. Science 263: 1136-1139.

Jabado, N., Le Deist, F., Fisher, A., and Hivroz, C. 1994. Interaction of HIV gp120 and anti-CD4 antibodies with the CD4 molecule on human CD4 ${ }^{+} \mathrm{T}$ cells inhibits the binding activity of NF-AT, NF-kappa B and AP-1, three nuclear factors regulating interleukin-2 gene enhancer activity. Eur J Immunol 24: 2646-2652.

Jauliac, S., Mazerolles, F., Jabado, N., Pallier, A., Bernard, F., Peake, J., Fischer, A., and Hivroz, C. 1998. Ligands of CD4 inhibit the association of phospholipase Cgamma1 with phosphoinositide 3 kinase in T cells: regulation of this association by the phosphoinositide 3 kinase activity. Eur J Immunol 28: 3183-3191.

Kahn, M., Sugawara, H., Mcgowan, P., Okuno, K., Nagoya, S., Hellstrom, K.E., Hellstrom, I., and Greenberg, P. 1991. $\mathrm{CD}^{+} \mathrm{T}$ cell clones specific for the human p97 melanomaassociated antigen can eradicate pulmonary metastases from a murine tumor expressing the p97 antigen. J. Immunol. 146: 3235-3241.

Kanda, N. and Watanabe, S. 2001. Regulatory roles of adenylate cyclase and cyclic nucleotide phosphodiesterases 1 and 4 in interleukin-13 production by activated human T cells. Biochem. Pharmacol. 62: 495507.

Karttunen, J. and Shastri, N. 1991. Measurement of ligandinduced activation in single viable T cells using the lacZ reporter gene. Proc Natl Acad Sci U S A 88: 3972-3976.

Kawasaki, H., Springett, G.M., Mochizuki, N., Toki, S., Nakaya, M., Matsuda, M., Housman, D.E., and Graybiel, A.M. 1998. A family of cAMP-binding proteins that directly activate Rap1. Science 282: 2275-2279.

Kern, P.S., Teng, M.K., Smolyar, A., Liu, J.H., Liu, J., Hussey, R.E., Spoerl, R., Chang, H.C., Reinherz, E.L., and Wang, J.H. 1998. Structural basis of CD8 coreceptor function revealed by crystallographic analysis of a murine CD8 alpha alpha ectodomain fragment in complex with H-2K. Immunity 9: 519-530.

Khor, B. and Sleckman, B.P. 2002. Allelic exclusion at the TCRbeta locus. Curr Opin Immunol 14: 230-234.

König, R. 2002. Interactions between MHC molecules and co-receptors of the TCR. Curr Opin Immunol 14: 75-83.

König, R., Fleury, S., and Germain, R.N. 1996. The structural basis of CD4-MHC class II interactions: coreceptor contributions to $\mathrm{T}$ cell receptor antigen recognition and oligomerization-dependent signal transduction. Curr. Top. Microbiol. Immunol. 205: 19-46.

König, R., Huang, L.Y., and Germain, R.N. 1992. MHC class II interaction with CD4 mediated by a region analogous to the MHC class I binding site for CD8. Nature 356: 796798.

König, R., Shen, X., and Germain, R.N. 1995. Involvement of both major histocompatibility complex class II alpha and beta chains in CD4 function indicates a role for ordered oligomerization in T cell activation. J. Exp. Med. 182: 779-787.

König, R., Shen, X., Maroto, R., and Denning, T.L. 2002. The role of CD4 in regulating homeostasis of $\mathrm{T}$ helper cells. Immunol Res 25: 115-130.

Kosugi, A., Sakakura, J., Yasuda, K., Ogata, M., and
Hamaoka, T. 2001. Involvement of SHP-1 tyrosine phosphatase in TCR-mediated signaling pathways in lipid rafts. Immunity 14: 669-680.

Krensky, A.M., Clayberger, C., Reiss, C.S., Strominger, J.L., and Burakoff, S.J. 1982. Specificity of OKT4+ cytotoxic T lymphocyte clones. J Immunol 129: 2001-2003.

Krummel, M.F., Sjaastad, M.D., Wulfing, C., and Davis, M.M. 2000. Differential clustering of CD4 and CD3zeta during T cell recognition. Science 289: 1349-1352.

Laxminarayana, D. and Kammer, G.M. 1996. Activation of type I protein kinase A during receptor-mediated human T lymphocyte activation. J. Immunol. 156: 497-506.

Leitenberg, D., Balamuth, F., and Bottomly, K. 2001. Changes in the $T$ cell receptor macromolecular signaling complex and membrane microdomains during $T$ cell development and activation. Semin Immunol 13: 129-138.

Leung, R.K., Thomson, K., Gallimore, A., Jones, E., Van Den Broek, M., Sierro, S., Alsheikhly, A.R., Mcmichael, A., and Rahemtulla, A. 2001. Deletion of the CD4 silencer element supports a stochastic mechanism of thymocyte lineage commitment. Nat Immunol 2: 1167-1173.

Li, L., Yee, C., and Beavo, J.A. 1999. CD3- and CD28dependent induction of PDE7 required for $T$ cell activation. Science 283: 848-851.

Lingk, D.S., Chan, M.A., and Gelfand, E.W. 1990. Increased cyclic adenosine monophosphate levels block progression but not initiation of human T cell proliferation. J Immunol 145: 449-455.

Lippert, E., Jacques, Y., and Hermouet, S. 2000. Positive regulation of human $T$ cell activation by $G_{i 2}$ proteins and interleukin-8. J. Leukoc. Biol. 67: 742-748.

Lograsso, P.V., Hawkins, J., Frank, L.J., Wisniewski, D., and Marcy, A. 1996. Mechanism of activation for Zap-70 catalytic activity. Proc Natl Acad Sci U S A 93: 1216512170.

Loh, C., Carew, J.A., Kim, J., Hogan, P.G., and Rao, A. 1996. T-cell receptor stimulation elicits an early phase of activation and a later phase of deactivation of the transcription factor NFAT1. Mol Cell Biol 16: 3945-3954.

Luo, K.X. and Sefton, B.M. 1990. Cross-linking of T-cell surface molecules CD4 and CD8 stimulates phosphorylation of the lck tyrosine protein kinase at the autophosphorylation site. Mol. Cell. Biol. 10: 5305-5313.

Lynch, G.W., Sloane, A.J., Raso, V., Lai, A., and Cunningham, A.L. 1999. Direct evidence for native CD4 oligomers in lymphoid and monocytoid cells. Eur. J. Immunol. 29: 2590-2602.

Mackenzie, S.J., Yarwood, S.J., Peden, A.H., Bolger, G.B., Vernon, R.G., and Houslay, M.D. 1998. Stimulation of p70S6 kinase via a growth hormone-controlled phosphatidylinositol 3-kinase pathway leads to the activation of a PDE4A cyclic AMP-specific phosphodiesterase in 3T3-F442A preadipocytes. Proc Natl Acad Sci U S A 95: 3549-3554.

Magnan, A., Di Bartolo, V., Mura, A.M., Boyer, C., Richelme, M., Lin, Y.L., Roure, A., Gillet, A., Arrieumerlou, C., Acuto, O., Malissen, B., and Malissen, M. 2001. T cell development and $\mathrm{T}$ cell responses in mice with mutations affecting tyrosines 292 or 315 of the ZAP-70 protein tyrosine kinase. J Exp Med 194: 491-505.

Manganiello, V.C., Murata, T., Taira, M., Belfrage, P., and 
Degerman, E. 1995. Diversity in cyclic nucleotide phosphodiesterase isoenzyme families. Arch. Biochem. Biophys. 322: 1-13.

Maroto, R., Shen, X., and König, R. 1999. Requirement for efficient interactions between CD4 and MHC class II molecules for survival of resting $\mathrm{CD}^{+} \mathrm{T}$ lymphocytes in vivo and for activation-induced cell death. J Immunol 162: 5973-5980.

Marschner, S., Hunig, T., Cambier, J.C., and Finkel, T.H. 2002. Ligation of human CD4 interferes with antigeninduced activation of primary $\mathrm{T}$ cells. Immunol Lett 82 : 131-139.

May, W.S., Lapetina, E.G., and Cuatrecasas, P. 1986. Intracellular activation of protein kinase $C$ and regulation of the surface transferrin receptor by diacylglycerol is a spontaneously reversible process that is associated with rapid formation of phosphatidic acid. Proc Natl Acad Sci U S A 83: 1281-1284.

Metz, D.P., Farber, D.L., König, R., and Bottomly, K. 1997. Regulation of memory CD4 T cell adhesion by CD4-MHC class II interaction. J. Immunol. 159: 2567-2573.

Meuer, S.C., Hussey, R.E., Hodgdon, J.C., Hercend, T., Schlossman, S.F., and Reinherz, E.L. 1982. Surface structures involved in target recognition by human cytotoxic T lymphocytes. Science 218: 471-473.

Milia, E., Di Somma, M.M., Majolini, M.B., Ulivieri, C., Somma, F., Piccolella, E., Telford, J.L., and Baldari, C.T. 1997. Gene activating and proapoptotic potential are independent properties of different CD4 epitopes. Mol. Immunol. 34: 287-296.

Monks, C.R., Freiberg, B.A., Kupfer, H., Sciaky, N., and Kupfer, A. 1998. Three-dimensional segregation of supramolecular activation clusters in T cells. Nature 395: 82-86.

Negulescu, P.A., Krasieva, T.B., Khan, A., Kerschbaum, H.H., and Cahalan, M.D. 1996. Polarity Of T Cell Shape, Motility, and Sensitivity to Antigen. Immunity 4: 421-430. Negulescu, P.A., Shastri, N., and Cahalan, M.D. 1994. Intracellular calcium dependence of gene expression in single T lymphocytes. Proc Natl Acad Sci U S A 91: 28732877.

Niedermann, G. 2002. Immunological functions of the proteasome. Curr Top Microbiol Immunol 268: 91-136.

Norbury, C.C., Princiotta, M.F., Bacik, I., Brutkiewicz, R.R., Wood, P., Elliott, T., Bennink, J.R., and Yewdell, J.W. 2001. Multiple antigen-specific processing pathways for activating naive $\mathrm{CD}^{+} \mathrm{T}$ cells in vivo. J Immunol 166: 43554362.

Nourse, J., Firpo, E., Flanagan, W.M., Coats, S., Polyak, K., Lee, M.H., Massague, J., Crabtree, G.R., and Roberts, J.M. 1994. Interleukin-2-mediated elimination of the p27 Kip1 cyclin-dependent kinase inhibitor prevented by rapamycin. Nature 372: 570-573.

Paliogianni, F., Kincaid, R.L., and Boumpas, D.T. 1993. Prostaglandin E2 and other cyclic AMP elevating agents inhibit interleukin 2 gene transcription by counteracting calcineurin-dependent pathways. J. Exp. Med. 178: 18131817.

Pallier, A., Jauliac, S., Jabado, N., Fischer, A., and Hivroz, C. 1998. Differential CD4-dependent inhibition of JNK but not Erk-2 activities in human naive and memory $C D 4^{+} \mathrm{T}$ cell populations. Int. Immunol. 10: 869-876.

Papoff, G., Hausler, P., Eramo, A., Pagano, M.G., Di Leve, G., Signore, A., and Ruberti, G. 1999. Identification and characterization of a ligand-independent oligomerization domain in the extracellular region of the CD95 death receptor. J. Biol. Chem. 274: 38241-38250.

Paz, P.E., Wang, S.J., Clarke, H., Lu, X.B., Stokoe, D., and Abo, A. 2001. Mapping the Zap-70 phosphorylation sites on LAT (linker for activation of T cells) required for recruitment and activation of signalling proteins in $\mathrm{T}$ cells. Biochemical Journal 356: 461-471.

Prasad, K.V., Kapeller, R., Janssen, O., Repke, H., DukeCohan, J.S., Cantley, L.C., and Rudd, C.E. 1993. Phosphatidylinositol (PI) 3-kinase and PI 4-kinase binding to the CD4-p56 ${ }^{\text {lck }}$ complex: the p56 ${ }^{\text {lck }} \mathrm{SH} 3$ domain binds to PI 3-kinase but not PI 4-kinase. Mol. Cell. Biol. 13: 7708-7717.

Qian, D., Griswold-Prenner, I., Rosner, M.R., and Fitch, F.W. 1993. Multiple components of the T cell antigen receptor complex become tyrosine-phosphorylated upon activation. J Biol Chem 268: 4488-4493.

Rabinowitz, J.D., Beeson, C., Wulfing, C., Tate, K., Allen, P.M., Davis, M.M., and Mcconnell, H.M. 1996. Altered T cell receptor ligands trigger a subset of early $\mathrm{T}$ cell signals. Immunity 5: 125-135.

Ramstad, C., Sundvold, V., Johansen, H.K., and Lea, T. 2000. cAMP-dependent protein kinase (PKA) inhibits T cell activation by phosphorylating ser- 43 of raf- 1 in the MAPK/ERK pathway. Cell Signal 12: 557-563.

Ratcliffe, M.J., Coggeshall, K.M., Newell, M.K., and Julius, M.H. 1992. T cell receptor aggregation, but not dimerization, induces increased cytosolic calcium concentrations and reveals a lack of stable association between CD4 and the T cell receptor. J. Immunol. 148: 1643-1651.

Raulet, D.H., Garman, R.D., Saito, H., and Tonegawa, S. 1985. Developmental regulation of T-cell receptor gene expression. Nature 314: 103-107.

Ravichandran, K.S., Lee, K.K., Songyang, Z., Cantley, L.C., Burn, P., and Burakoff, S.J. 1993. Interaction of Shc with the zeta chain of the T cell receptor upon T cell activation. Science 262: 902-905.

Res, P. and Spits, H. 1999. Developmental stages in the human thymus. Seminars in Immunology 11: 39-46.

Rizzo, L.V., Silver, P., Wiggert, B., Hakim, F., Gazzinelli, R.T., Chan, C.C., and Caspi, R.R. 1996. Establishment and characterization of a murine $\mathrm{CD} 4^{+} \mathrm{T}$ cell line and clone that induce experimental autoimmune uveoretinitis in B10.A mice. J. Immunol. 156: 1654-1660.

Robey, E. and Fowlkes, B.J. 1994. Selective events in T cell development. Annu Rev Immunol 12: 675-705.

Rodriguez-Frade, J.M., Vila-Coro, A.J., De Ana, A.M., Albar, J.P., Martinez, A.C., and Mellado, M. 1999. The chemokine monocyte chemoattractant protein-1 induces functional responses through dimerization of its receptor CCR2. Proc. Natl. Acad. Sci. U. S. A. 96: 3628-3633.

Rooney, J.W., Sun, Y.L., Glimcher, L.H., and Hoey, T. 1995. Novel NFAT sites that mediate activation of the interleukin2 promoter in response to T-cell receptor stimulation. Mol. Cell. Biol. 15: 6299-6310.

Salter, R.D., Benjamin, R.J., Wesley, P.K., Buxton, S.E., 
Garrett, T.P., Clayberger, C., Krensky, A.M., Norment, A.M., Littman, D.R., and Parham, P. 1990. A binding site for the T-cell co-receptor CD8 on the alpha 3 domain of HLA-A2. Nature 345: 41-46.

Schoenberger, S.P., Toes, R.E., Van Der Voort, E.I., Offringa, R., and Melief, C.J. 1998. T-cell help for cytotoxic T lymphocytes is mediated by CD40-CD40L interactions. Nature 393: 480-483.

Shen, X., Hu, B., Mcphie, P., Wu, X., Fox, A., Germain, R.N., and König, R. 1996. Peptides corresponding to CD4-interacting regions of murine $\mathrm{MHC}$ class II molecules modulate immune responses of $\mathrm{CD}^{+} \mathrm{T}$ lymphocytes in vitro and in vivo. J. Immunol. 157: 87-100.

Shen, X. and König, R. 2001. Post-thymic selection of peripheral $\mathrm{CD}^{+}$T-lymphocytes on class II major histocompatibility antigen-bearing cells. Cell. Mol. Biol. 47: 87-96.

Singer, A. 2002. New perspectives on a developmental dilemma: the kinetic signaling model and the importance of signal duration for the CD4/CD8 lineage decision. Curr Opin Immunol 14: 207-215.

Skalhegg, B.S., Landmark, B.F., Doskeland, S.O., Hansson, V., Lea, T., and Jahnsen, T. 1992. Cyclic AMPdependent protein kinase type I mediates the inhibitory effects of $33^{\prime}, 5^{\prime}$-cyclic adenosine monophosphate on cell replication in human T lymphocytes. J. Biol. Chem. 267: 15707-15714.

Skalhegg, B.S., Tasken, K., Hansson, V., Huitfeldt, H.S., Jahnsen, T., and Lea, T. 1994. Location of CAMPdependent protein kinase type I with the TCR-CD3 complex. Science 263: 84-87.

Sleckman, B.P., Rosenstein, Y., Igras, V.E., Greenstein, J.L., and Burakoff, S.J. 1991. Glycolipid-anchored form of CD4 increases intercellular adhesion but is unable to enhance T cell activation. J. Immunol. 147: 428-431.

Sloan-Lancaster, J., Steinberg, T.H., and Allen, P.M. 1997. Selective loss of the calcium ion signaling pathway in $T$ cells maturing toward a T helper 2 phenotype. J Immunol 159: 1160-1168.

Snow, E.C., Pittner, B., and Reid, S. 1994. T helper cell regulation of normal and neoplastic $B$ cell growth. Semin. Immunol. 6: 311-326.

Soderling, S.H. and Beavo, J.A. 2000. Regulation of cAMP and CGMP signaling: new phosphodiesterases and new functions. Curr. Op. Cell Biol. 12: 174-179.

Sommers, C.L., Menon, R.K., Grinberg, A., Zhang, W., Samelson, L.E., and Love, P.E. 2001. Knock-in mutation of the distal four tyrosines of linker for activation of T cells blocks murine T cell development. J Exp Med 194: 135142.

Staples, K.J., Bergmann, M., Barnes, P.J., and Newton, R. 2000. Stimulus-specific inhibition of IL- 5 by cAMPelevating agents and IL-10 reveals differential mechanisms of action. Biochem Biophys Res Commun 273: 811-815.

Strong, J., Wang, Q., and Killeen, N. 2001. Impaired survival of $\mathrm{T}$ helper cells in the absence of CD4. Proc Natl Acad Sci U S A 98: 2566-2571.

Su, M.W., Yu, C.L., Burakoff, S.J., and Jin, Y.J. 2001. Targeting Src homology 2 domain-containing tyrosine phosphatase (SHP-1) into lipid rafts inhibits CD3-induced T cell activation. J Immunol 166: 3975-3982.

Sugiyama, H., Chen, P., Hunter, M.G., and Sitkovsky, M.V.
1997. Perturbation of the expression of the catalytic subunit $C$ alpha of cyclic AMP-dependent protein kinase inhibits TCR-triggered secretion of IL-2 by T helper hybridoma cells. J Immunol 158: 171-179.

Sun, Z.Y.J., Kim, H.S., Wagner, G., and Reinherz, E.L. 2001. Mechanisms contributing to T cell receptor signaling and assembly revealed by the solution structure of an ectodomain fragment of the CD3 epsilon gamma heterodimer. Cell 105: 913-923.

Surh, C.D. and Sprent, J. 1994. T-cell apoptosis detected in situ during positive and negative selection in the thymus. Nature 372: 100-103.

Swain, S.L. 1981. Significance of Lyt phenotypes: Lyt2 antibodies block activities of $T$ cells that recognize class 1 major histocompatibility complex antigens regardless of their function. Proc Natl Acad Sci U S A 78: 7101-7105.

Swain, S.L. 1983. T cell subsets and the recognition of MHC class. Immunol Rev 74: 129-142.

Tang, K.M., Jang, E.K., and Haslam, R.J. 1997. Expression and mutagenesis of the catalytic domain of cGMPinhibited phosphodiesterase (PDE3) cloned from human platelets. Biochem J 323 ( Pt 1): 217-224.

Taniuchi, I., Sunshine, M.J., Festenstein, R., and Littman, D.R. 2002. Evidence for distinct CD4 silencer functions at different stages of thymocyte differentiation. Mol Cell 10: 1083-1096.

Taylor-Robinson, A.W. and Phillips, R.S. 1992. Functional characterization of protective $\mathrm{CD} 4^{+} \mathrm{T}$-cell clones reactive to the murine malaria parasite Plasmodium chabaudi. Immunology 77: 99-105.

Telfer, J.C. and Rudd, C.E. 1991. A 32-kD GTP-binding protein associated with the CD4-p56 lck and CD8-p56 ${ }^{\text {lck }} \mathrm{T}$ cell receptor complexes. Science 254: 439-441.

Timmerman, L.A., Clipstone, N.A., Ho, S.N., Northrop, J.P., and Crabtree, G.R. 1996. Rapid shuttling of NF-AT in discrimination of $\mathrm{Ca}^{2+}$ signals and immunosuppression. Nature 383: 837-840.

Tsien, R.Y., Pozzan, T., and Rink, T.J. 1982. T-cell mitogens cause early changes in cytoplasmic free $\mathrm{Ca}^{2+}$ and membrane potential in lymphocytes. Nature 295: 68-71.

Van Oirschot, B.A., Stahl, M., Lens, S.M., and Medema, R.H. 2001. Protein kinase A regulates expression of p27(kip1) and cyclin D3 to suppress proliferation of leukemic T cell lines. J Biol Chem 276: 33854-33860.

Vang, T., Torgersen, K.M., Sundvold, V., Saxena, M., Levy, F.O., Skalhegg, B.S., Hansson, V., Mustelin, T., and Tasken, K. 2001. Activation of the $\mathrm{COOH}$-terminal Src kinase (Csk) by cAMP-dependent protein kinase inhibits signaling through the T cell receptor. J Exp Med 193: 497507.

Veillette, A., Bookman, M.A., Horak, E.M., Samelson, L.E., and Bolen, J.B. 1989. Signal transduction through the CD4 receptor involves the activation of the internal membrane tyrosine-protein kinase p56 ${ }^{\mathrm{ck}}$. Nature 338: 257-259.

Walsh, D.A. and Van Patten, S.M. 1994. Multiple pathway signal transduction by the CAMP-dependent protein kinase. Faseb J 8: 1227-1236.

Weber, S. and Karjalainen, K. 1993. Mouse CD4 binds $\mathrm{MHC}$ class II with extremely low affinity. Int. Immunol. 5: 695-698.

Weil, R., Cloutier, J.F., Fournel, M., and Veillette, A. 1995. 
Regulation of Zap-70 by Src family tyrosine protein kinases in an antigen-specific T-cell line. J Biol Chem 270: 2791-2799.

Weinberg, R.A. 1995. The retinoblastoma protein and cell cycle control. Cell 81: 323-330.

Weiss, M.J., Daley, J.F., Hodgdon, J.C., and Reinherz, E.L. 1984. Calcium dependency of antigen-specific (T3-Ti) and alternative (T11) pathways of human T-cell activation. Proc Natl Acad Sci U S A 81: 6836-6840.

Welsh, M., Songyang, Z., Frantz, J.D., Trub, T., Reedquist, K.A., Karlsson, T., Miyazaki, M., Cantley, L.C., Band, H., and Shoelson, S.E. 1998. Stimulation through the T cell receptor leads to interactions between SHB and several signaling proteins. Oncogene 16: 891-901.

Werlen, G., Hausmann, B., and Palmer, E. 2000. A motif in the alphabeta T-cell receptor controls positive selection by modulating ERK activity. Nature 406: 422-426.

White, D.W. and Tartaglia, L.A. 1999. Evidence for ligandindependent homo-oligomerization of leptin receptor (OB$\mathrm{R}$ ) isoforms: a proposed mechanism permitting productive long-form signaling in the presence of excess short-form expression. J. Cell. Biochem. 73: 278-288.

Williams, C.B., Engle, D.L., Kersh, G.J., Michael White, J., and Allen, P.M. 1999. A kinetic threshold between negative and positive selection based on the longevity of the T cell receptor-ligand complex. J Exp Med 189: 1531-1544.

Wu, H., Kwong, P.D., and Hendrickson, W.A. 1997. Dimeric association and segmental variability in the structure of human CD4. Nature 387: 527-530.

Wülfing, C. and Davis, M.M. 1998. A receptor/cytoskeletal movement triggered by costimulation during $\mathrm{T}$ cell activation. Science 282: 2266-2269.

Wülfing, C., Rabinowitz, J.D., Beeson, C., Sjaastad, M.D., Mcconnell, H.M., and Davis, M.M. 1997. Kinetics and extent of $\mathrm{T}$ cell activation as measured with the calcium signal. J. Exp. Med. 185: 1815-1825.

Xiong, Y., Kern, P., Chang, H.C., and Reinherz, E.L. 2001.
T cell receptor binding to a pMHCII ligand is kinetically distinct from and independent of CD4. J. Biol. Chem. 276: 5659-5667.

Yablonski, D. and Weiss, A. 2001. Mechanisms of signaling by the hematopoietic-specific adaptor proteins, SLP-76 and LAT and their B cell counterpart, BLNK/SLP-65. Adv Immunol 79: 93-128.

Yasutomo, K., Doyle, C., Miele, L., and Germain, R.N. 2000. The duration of antigen receptor signalling determines $\mathrm{CD}^{+}$versus CD8 ${ }^{+} \mathrm{T}$-cell lineage fate. Nature 404: 506510.

Yewdell, J.W. 2001. Not such a dismal science: the economics of protein synthesis, folding, degradation and antigen processing. Trends Cell Biol 11: 294-297.

York, R.D., Yao, H., Dillon, T., Ellig, C.L., Eckert, S.P., Mccleskey, E.W., and Stork, P.J. 1998. Rap1 mediates sustained MAP kinase activation induced by nerve growth factor. Nature 392: 622-626.

Zal, T., Zal, M.A., and Gascoigne, N.R. 2002. Inhibition of $T$ cell receptor-coreceptor interactions by antagonist ligands visualized by live FRET imaging of the Thybridoma immunological synapse. Immunity 16: 521534.

Zhang, W., Sloan-Lancaster, J., Kitchen, J., Trible, R.P., and Samelson, L.E. 1998. LAT: the ZAP-70 tyrosine kinase substrate that links $T$ cell receptor to cellular activation. Cell 92: 83-92.

Zhou, W. and König, R. 2003. T cell receptor-independent CD4 signalling: CD4-MHC class II interactions regulate intracellular calcium and cyclic AMP. Cell. Signal. 15: 751762.

Zidek, Z. 1999. Adenosine - cyclic AMP pathways and cytokine expression. Eur Cytokine Netw 10: 319-328.

Zou, Y.R., Sunshine, M.J., Taniuchi, I., Hatam, F., Killeen, N., and Littman, D.R. 2001. Epigenetic silencing of CD4 in $\mathrm{T}$ cells committed to the cytotoxic lineage. Nat Genet 29: 332-336. 


\section{Further Reading}

Caister Academic Press is a leading academic publisher of advanced texts in microbiology, molecular biology and medical research. Full details of all our publications at caister.com

- MALDI-TOF Mass Spectrometry in Microbiology Edited by: M Kostrzewa, S Schubert (2016) www.caister.com/malditof

- Aspergillus and Penicillium in the Post-genomic Era Edited by: RP Vries, IB Gelber, MR Andersen (2016) www.caister.com/aspergillus2

- The Bacteriocins: Current Knowledge and Future Prospects Edited by: RL Dorit, SM Roy, MA Riley (2016)

www.caister.com/bacteriocins

- Omics in Plant Disease Resistance Edited by: V Bhadauria (2016) www.caister.com/opd

- Acidophiles: Life in Extremely Acidic Environments Edited by: R Quatrini, DB Johnson (2016) www.caister.com/acidophiles

- Climate Change and Microbial Ecology: Current Research and Future Trend

Edited by: J Marxsen (2016)

www.caister.com/climate

- Biofilms in Bioremediation: Current Research and Emerging Technologies

Edited by: G Lear (2016)

www.caister.com/biorem

- Microalgae: Current Research and Applications Edited by: MN Tsaloglou (2016) www.caister.com/microalgae

- Gas Plasma Sterilization in Microbiology: Theory, Applications, Pitfalls and New Perspectives Edited by: H Shintani, A Sakudo (2016) www.caister.com/gasplasma

- Virus Evolution: Current Research and Future Directions Edited by: SC Weaver, M Denison, M Roossinck, et al. (2016) www.caister.com/virusevol

- Arboviruses: Molecular Biology, Evolution and Control Edited by: N Vasilakis, DJ Gubler (2016) www.caister.com/arbo

- Shigella: Molecular and Cellular Biology Edited by: WD Picking, WL Picking (2016) www.caister.com/shigella

-Aquatic Biofilms: Ecology, Water Quality and Wastewater Treatment

Edited by: AM Romaní, H Guasch, MD Balaguer (2016)

www.caister.com/aquaticbiofilms

- Alphaviruses: Current Biology

Edited by: S Mahalingam, L Herrero, B Herring (2016)

www.caister.com/alpha

- Thermophilic Microorganisms

Edited by: F Li (2015)

www.caister.com/thermophile
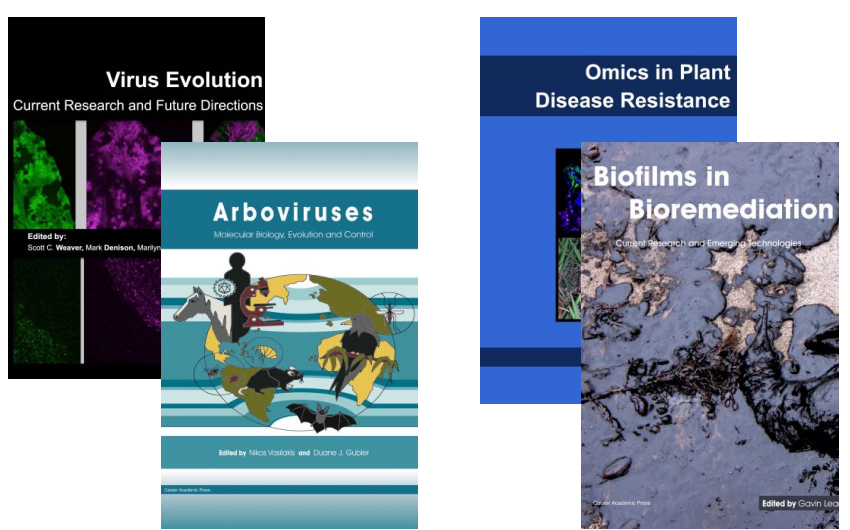
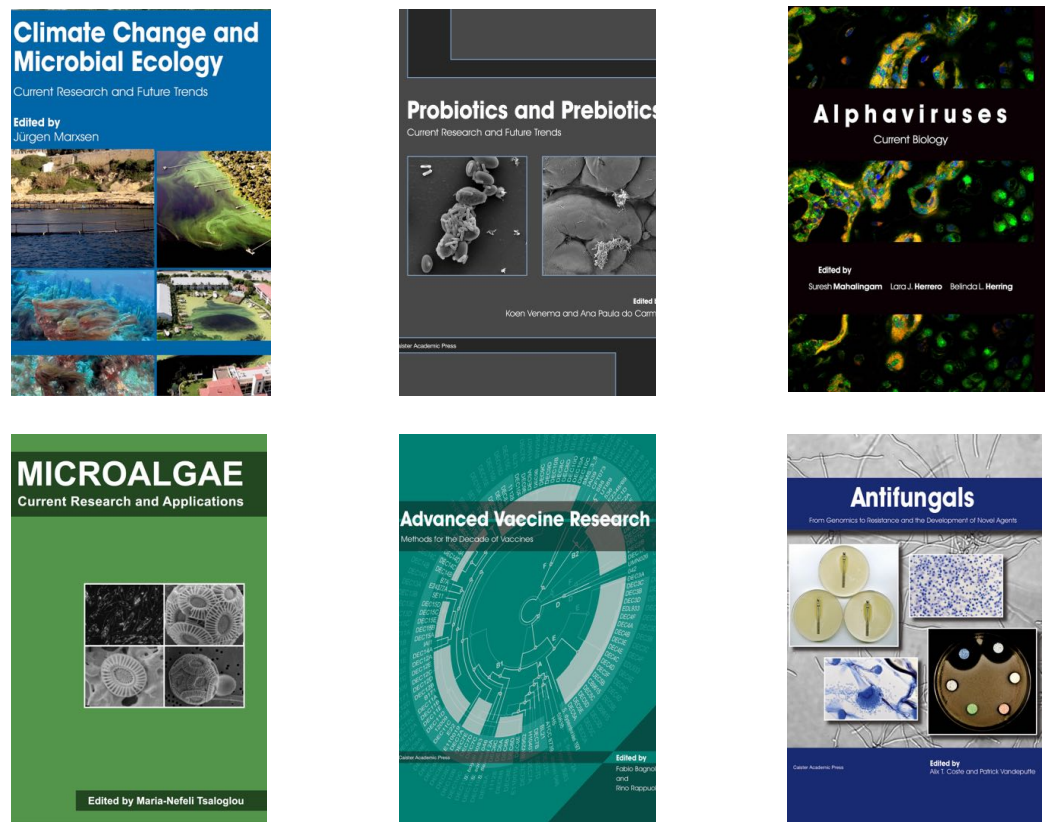

- Flow Cytometry in Microbiology: Technology and Applications Edited by: MG Wilkinson (2015) www.caister.com/flow

- Probiotics and Prebiotics: Current Research and Future Trends Edited by: K Venema, AP Carmo (2015) www.caister.com/probiotics

- Epigenetics: Current Research and Emerging Trends Edited by: BP Chadwick (2015) www.caister.com/epigenetics2015

- Corynebacterium glutamicum: From Systems Biology to Biotechnological Applications

Edited by: A Burkovski (2015)

www.caister.com/cory2

- Advanced Vaccine Research Methods for the Decade of Vaccines

Edited by: F Bagnoli, R Rappuoli (2015)

www.caister.com/vaccines

- Antifungals: From Genomics to Resistance and the Development of Novel Agents

Edited by: AT Coste, P Vandeputte (2015)

www.caister.com/antifungals

- Bacteria-Plant Interactions: Advanced Research and Future Trends Edited by: J Murillo, BA Vinatzer, RW Jackson, et al. (2015) www.caister.com/bacteria-plant

\section{- Aeromonas}

Edited by: J Graf (2015)

www.caister.com/aeromonas

- Antibiotics: Current Innovations and Future Trends

Edited by: S Sánchez, AL Demain (2015)

www.caister.com/antibiotics

- Leishmania: Current Biology and Contro Edited by: S Adak, R Datta (2015) www.caister.com/leish2

- Acanthamoeba: Biology and Pathogenesis (2nd edition) Author: NA Khan (2015)

www.caister.com/acanthamoeba2

- Microarrays: Current Technology, Innovations and Applications Edited by: Z He (2014)

www.caister.com/microarrays2

- Metagenomics of the Microbial Nitrogen Cycle: Theory, Methods and Applications

Edited by: D Marco (2014)

www.caister.com/n2 